\title{
Uncovering the digitalization impact on consumer decision-making for checking accounts in banking
}

\author{
Maik Dehnert ${ }^{1} \mathbb{D} \cdot$ Josephine Schumann ${ }^{2}$
}

Received: 29 April 2021 / Accepted: 10 January 2022 / Published online: 5 February 2022

(c) The Author(s) 2022

\begin{abstract}
Checking account providers must understand the importance of digital and non-digital service attributes across different customer segments to achieve a product-market fit in digitalization. In particular, various latent personal characteristics influence customer choices in digital banking. However, there is only limited research on banking customer behavior beyond the technology acceptance model, and none that explores customer preferences for checking accounts experimentally. Against this background, we present the results of a discrete choice experiment on customer preferences towards checking accounts in Germany. The outcome of the paper is a detailed quantitative assessment of the relationships between checking account service attributes and a set of latent influencing factors on choice. While customer service experience, the scope of services, and professional expertise are identified as re-occurring critical aspects for customers when choosing their banking service provider, the type of provider and digital product innovation showed little impact on customer choice overall. In multigroup analyses, we reveal the moderating impact of influencing factors on the preference of checking account service attributes. Additional segmentation analyses point to six customer segments from which four still prefer a traditional operating model. The largest segment of traditional product-innovative customers prefers digitalized, i.e., data-driven checking accounts in a mixed-mode with human customer advisory and on-site branch services from a traditional bank. At the other end of the spectrum, a small innovative Fintech customer segment, influenced by non-pragmatism and social norms, prefers a purely digital operating model with data-driven applications in banking.
\end{abstract}

Keywords Digitalization $\cdot$ Banking $\cdot$ Checking account $\cdot$ Consumer behavior $\cdot$ Digital transformation $\cdot$ Fintech

JEL Classification M150

\section{Introduction}

The primary checking account has always been an anchor point for house bank relationships of the traditional banking business. However, as digitalization is changing the nature of product and service offerings in banking, customer

Responsible Editor: Rainer Alt

Maik Dehnert

dehnert@uni-potsdam.de

Josephine Schumann

schumann4@uni-potsdam.de

1 Chair of Business Informatics, esp. Processes and Systems, University of Potsdam, August-Bebel-Str. 89, 14482 Potsdam, Germany

2 University of Potsdam, Potsdam, Germany preferences for traditional products such as checking accounts may also have changed. Based on digital financial technologies, new market players ("Fintech") have introduced new innovative offerings to the banking industry (e.g., Alt \& Puschmann, 2012; Gomber et al., 2018). Neobanks such as Revolut or N26 already provide fully digital checking accounts. Such innovative digital offerings increasingly challenge the traditionally strong customer relationships with incumbent banks. Incumbent banks have started to react to these developments and innovated their product offerings in many places (Dehnert, 2020).

Many studies have been conducted on the usage and adoption of checking accounts. However, few studies go beyond the limited technology acceptance model to examine customer preferences in banking (Carbo-Valverde et al., 2020). Influencing factors, such as trust, expressiveness, or personal values, may also impact customer preferences for 
checking accounts (Pousttchi and Dehnert, 2018). While survey studies still predominate, only very few experimental studies have been conducted in banking (Hoehle et al., 2012). Moreover, the future of checking accounts is also widely debated in practice. There is a broad opinion spectrum between bank traditionalists and Fintech evangelists on which service attributes will remain relevant in the future and what banking innovations will catch on. Hence, the future role of traditional banks as checking account providers and a trusted money depository on the one hand and the necessity of branches and human customer advisory on the other is highly controversial (Skinner, 2021).

Against this background, this paper analyzes the customer preferences towards primary checking accounts with a discrete choice experiment. We answer the following research questions: What traditional and digital service attributes do German customers prefer, and how are latent influencing factors linked to their choices? Researching the observed heterogeneities, we explore how the choice of service attributes is moderated by influencing factors, such as personal trust-related, social, and attitudinal conditions. We further explore the unobserved heterogeneities to derive a set of latent customer segments. The outcome of the paper is a set of tested hypotheses on the importance of digital and non-digital service attributes, their interaction with latent influencing factors, and the description of customer segments. We contribute to digital product and service innovation research. Our findings provide bank managers with new insights to achieve a product-market fit for primary checking accounts.

The paper is structured as follows: In the next section, we introduce the theoretical background of our study. In section three, we describe the methodology for our quantitative analyses. Section four presents the results, i.e., direct effects analysis, moderating effects analysis, and the segmentation results for the unobserved heterogeneities. In section five, we discuss our results from a checking account service attribute perspective. In the last section, we establish theoretical and practical implications, discuss the limitations of the study, and provide avenues for future research.

\section{Theoretical background}

In this section, we provide the theoretical background and the research model for this study regarding the service attributes and the latent influencing factors on the choice of checking accounts.

\section{Consumer-decision making in digital banking}

Understanding consumer decision-making (CDM) is key to solving market planning problems, given the increasing spread of digital product offerings across customer segments (Blackwell et al., 2002; Schiffman \& Kanuk, 1997; Solomon et al., 2013), especially in the financial services domain (e.g., Milner \& Rosenstreich, 2013; van Raaij, 2016). In particular, digitalization changes CDM in banking (Pousttchi and Dehnert, 2018). However, studies that explored the digitalization impact on CDM in banking in developed countries are already quite outdated (Dick, 2008; Iqbal et al., 2003; Verma et al., 2004). More recent results suggest that consumer characteristics, needs, and perceptions drive CDM in banking, providing the opportunity for customer segmentation (Carbo-Valverde et al., 2020). Related research also examines the omnichannel behavior of banking customers (Fang et al., 2021; Zhou et al., 2020). Practitioners instead speculate that traditional customer segmentation is no longer effective and that customer usage paradigms must be considered (e.g., The Financial Brand, 2017). Therefore, we would like to explore this field of tension across numerous publications, especially from practice.

\section{Random utility theory}

We opted for a discrete choice experiment to examine consumer preferences in this study. Discrete choice experiments represent the decision complexity adequately and more realistically than survey studies since compensatory $C D M$ can be measured appropriately. Hence, discrete choice experiments are precious for research on checking accounts that are low to mid involvement products (Pousttchi and Dehnert, 2018). Discrete choice experiments present combinations of product or service attributes. Accordingly, we develop hypothetical decision situations for the participants of our experiment who have to decide between different product alternatives in a competitive market scenario (Hair et al., 2019). For each choice set, the participants must decide on one concrete product alternative or choose a 'none' option that is included to increase the realism of the experiment. The different choice sets presented as stimuli are evaluated based on latent personal preferences and finally trigger a choice decision (Solomon et al., 2013). The underlying choice model is based on random utility theory (Louviere et al., 2010). An individual study participant is regarded as a rational decision-maker who wants to maximize the utility relative to his or her choice. A customer is most likely to choose a product that provides the highest utility (McFadden, 1984). The utility attributed to the good or service consists of a systematic component, which depends on the characteristics, and a random component. The systematic component can be statistically inferred via the observation of choices. Thus, the path coefficient for the choice of a specific attribute can be estimated. The random utility component is not observable and is an error term in the statistical sense. Depending on the assumption about the distribution 
of the error terms, different statistical models can be used for choice model evaluation. To this end, influencing factors such as latent personal characteristics can also be included in choice modeling (Ben-Akiva et al., 2002; Louviere et al., 2008).

\section{Research model}

\section{Service attributes}

The service attributes must be identified first. When designing discrete choice experiments, there is always a tradeoff between the number of attributes and the number of choice sets on which a participant can meaningfully decide in a concentrated manner. The CDM literature recommends that a discrete choice set consist of five to nine attributes (Street $\&$ Burgess, 2007). This literature also recommends creating suitable categories to reduce the number of attributes in a meaningful way.

For this purpose, we evaluated available practitioner studies on checking accounts and collected the attributes which find recurring relevance in recent discussions (e.g., King, 2019; Kinting \& Wißmann, 2016; McKinsey, 2019b; Roland Berger, 2015; Skinner, 2014). Many practitioner studies have focused on the role of Fintech as novel checking account providers and the future of traditional banks (Skinner, 2020), the accessibility of the account service (esp. the role of the branch: Roland Berger, 2021; or new forms, such as pop-up stores: King, 2019), as well as the service experience and quality related to traditional and digital services (McKinsey 2019c; PwC, 2018, 2021). The rise of digital channels to access banking (King, 2019; PwC, 2020a, b), such as chatbots, is accompanied by a discussion around the future role of human customer advisory and expertise (Accenture, 2020). The debate on digital technologies further evolves around specific Fintech solutions, such as personal finance management (Pickford, 2019). Additional offerings beyond the core of a checking account are also discussed, such as credit cards or payment services (McKinsey, 2019a; Shevlin, 2021). Pricing is especially relevant regarding the lowinterest rate situation in European banking and the necessary adaptations to tackle cost pressure across all providers (Simon Kucher, 2019).

After collecting the relevant attributes from practice, we conducted 15 additional qualitative interviews with customers across different age groups. We asked them to describe and rank the most relevant attributes to complement our findings. The interviewees essentially stated the categories from the practitioner literature. Service attributes such as the availability of a personal contact person, branch accessibility, product innovation, and the experience, reliability, and pricing (costs) were important re-occurring aspects. While pricing is an important aspect to consider, we decided not to include this attribute as we wanted to focus on digital product and service innovation attributes. Free checking accounts are no longer economically feasible, so a pricing study would have required determining what people are willing to pay for primary and additional account services. Thus, we decided to keep the number of choices manageable for the participants and excluded the price attribute. Through the interviews, inconsistencies or overlaps in the combination of some product attributes could be identified, and our choice experiment design could be concretized.

Our selection was narrowed down to a final set of five service attributes strongly related to the impact of digitalization on CDM for checking accounts in banking. Altogether, the identified attributes address the provider type, the scope of services, the customer service experience, the digital product innovation (technology), and the human professional expertise. The attribute levels are varied with their characteristics related to the digitalization degree, resulting in eight hypothetical service offerings (i.e., choice sets). We conceptualized the following attribute levels:

- Provider type: Traditional bank, Fintech

- Service scope: Digital and analog access (branch/store), purely digital access

- Customer service experience: Very good service and intuitive operations, average service and cumbersome operations

- Digital product innovation: Standard app (only digital readouts), AI-based app (product and action recommendations matching personal financial/life situation)

- Professional expertise: High (personal experts available), low (digital assistants only)

In the following, we develop a set of hypotheses for the overall direct impact of the service attributes on choice.

Firstly, the provider type is an important criterion to account for in digital banking. Traditional incumbent banks and their Fintech counterparts, the neobanks, constitute the two types of customer account providers in the banking environment (Alt \& Puschmann, 2016; Eickhoff et al., 2017; Zavolokina et al., 2016). About one-third of the respondents could imagine switching from a traditional provider to a Fintech in a recent study (Jünger \& Mietzner, 2020). Personal brand preferences and the compatibility of brand types with consumer values might impact this. There could be a higher or lower valuation of traditional banks as the provider type. We suppose that German customers could still prefer a traditional bank due to its heritage value and nostalgic attachment. We hypothesize that the provider type "traditional bank" positively influences choice (H1).

Secondly, the scope of services is another potentially important criterion in digital banking. This attribute refers to the availability of stationary (i.e., non-digital) or purely 
digital services. Accordingly, a high scope of services includes the possibility of accessing one's account via a branch or store. Almost 75 percent of customers are still visiting bank branches (ING Group, 2019), although the frequency of branch visits decreases rapidly. However, the habits of customers might be changing in digital banking (Berger \& Messerschmidt, 2009). The dense traditional bank branch system is threatened to be replaced by digital distribution channels, such as mobile, video, and voice banking (Alt \& Puschmann, 2012). Fintech might also consider opening pop-up branches or integrating their digital services into existing stationary advisory settings of partners in the future. In sum, we expect both digital and non-digital services to be regarded more positively than digital services only (Zhou et al., 2020). Therefore, we hypothesize that a "high" scope of services positively influences choice (H2).

Thirdly, the customer service experience is an elementary attribute of services (Ding et al., 2011; Mbama \& Ezepue, 2018; Xin Ding et al., 2010). It entails positive affect, the level of customer mistreatment, and customer service behavior, including customer orientation (Groth et al., 2019). Convenience largely shapes the overall customer service experience (Berry et al., 2002; Collier \& Kimes, 2013; Dai $\&$ Salam, 2014). Plus, an overall positive customer service experience improves customer satisfaction (Helkkula et al., 2012; Homburg et al., 2017; Mocker \& Ross, 2013). However, both traditional banks and Fintech are reporting an increasing number of technical problems and failures in digitalization. Depending on how much customers pay attention to this attribute, they seek information, including their own or external experiences with checking account providers. Customers access information traditionally through exchanging personal experiences (e.g., word-of-mouth) or, increasingly, digitally via online reviews. Therefore, we hypothesize that customer service experience has a positive influence on choice (H3).

Fourthly, digital product innovation is referred to as banking innovations (Gomber et al., 2017, 2018). A digitalized bank could provide new types of applications based on transaction data analysis. Regarding checking accounts, AI-based digital assistants have gained currency (Maedche et al., 2019), such as in mobile apps, for example, the personal assistant "Erica" from Bank of America or the personal finance manager "Mint." These tools support customers in managing their personal finances (Gupta \& Tham, 2019; King, 2019). Despite its potential, the propensity to use digital personal assistants is still relatively low (Bud, 2020). On the other hand, standard mobile banking apps usually include financial overviews such as accounting records and overviews of monthly expenses. It is reasonable that customers are skeptical about novel digital products for checking accounts. Therefore, we hypothesize that "standard" digital product innovation positively influences choice (H4).
Finally, the importance of professional expertise is connected to the increased information transparency that gives self-efficacious customers an information advantage and power (Acar \& Puntoni, 2016). Customers obtain information on the Internet and carry out banking themselves. The information transparency may result in a loss of authority of customer advisors in banks (Kinting \& Wißmann, 2016). However, customers might also have complex financial issues that they would like to clarify personally with their house bank. Some customers may not need additional advisory services linked to their primary checking account. Consultations by human experts do not necessarily have to occur on-site but can also be provided digitally, for instance, via video channels, which are becoming more popular (Alt \& Puschmann, 2014). Although banking customers are increasingly engaged in self-service (Collier \& Kimes, 2013; Scherer et al., 2015), a customer advisor's availability and competence might still significantly influence the decision for a checking account (Laumann, 2013). Therefore, we hypothesize that "human" professional expertise exerts a positive influence on choice (H5).

\section{Influencing factors}

This section introduces a set of influencing factors on CDM for digital banking that we identified in a prior study (Pousttchi and Dehnert 2018), and we derive specific hypotheses regarding their moderating impact. We will refer to a moderating influence when we find that the service attributes' regression paths on choice differ significantly between the groups we formed from the influencing factors. The population of the respondents may, for example, favor a specific type of provider, but this may be different across the influencing factor segments.

Personal trust-related conditions We first distinguish consumer preferences that point to personal trust-related conditions. Trust is an essential prerequisite in many businessto-consumer interactions as it reduces uncertainty between transaction partners (Gefen et al. 2003). As it continues to be an essential aspect of digital commerce (Kim \& Peterson, 2017), it might especially be crucial for the banking industry (Breinich-Schilly, 2020). Calculative-based beliefs involve the emotional connection between individuals and the calculated compromises between perceived gains and pains in cost and benefit calculations (Lewis \& Weigert, 1985; Ologeanu-Taddei \& Vitari, 2020; Rousseau et al., 1998). Customers value when service providers are professionally reliable and act in their interest (Gefen and Straub, 2003). Structural assurances are defined as "the belief that success is likely because of contextual conditions such as promises, contracts, regulations and guarantees" (McKnight et al., 1998, p. 478). The perception of structural assurances could 
likely influence banking account choice. Traditionally, customers could judge the bank's trustworthiness, for instance, by the body language of the advisor and clues from the environment, such as the appearance of the on-site business. This interaction between trust and personal expertise diminishes because banking is increasingly shifting to online environments with less personal contact (Hurley et al., 2014). What remains is that customers are more likely to think that the checking account provider does not fit them if they have problems with customer service or feel that their needs are not adequately understood (Xu et al., 2011). However, digital banking innovations might also be closely related to trust (Brewster, 2016). Research shows that perceptions of interactivity could induce trust in mobile commerce (Lee, 2005). Recent surveys have shown that customers are increasingly willing to consider PayPal and Amazon for banking (Mistry, 2019; PYMNTS, 2019). We suppose that the greater the tendency to trust is, the more customers are inclined towards less traditional products. On the contrary, customers who attach greater importance to trust could prefer more traditional attributes. For those people, traditional banks might enjoy a heritage value (Almquist et al., 2016). Therefore, we hypothesize that personal trust-related conditions have a moderating influence on consumer choice (H-TRU) to positively influence the preference of traditional service attribute levels.

Social conditions We further look at the social conditions to reflect on consumers' socially constructed motives in banking, such as expressiveness (Nysveen et al., 2005), market mavenism (Feick \& Price, 1987), or subjective norms ( $\mathrm{Li}$ et al., 2008). The expressiveness construct addresses the ability to express style, image, and symbolic capital (Nysveen et al., 2005). More expressive consumers need to perceive that a bank product expresses below instrumental utility. We expect that more expressive people are more likely to be enthusiastic about a specific provider type than less expressive people. A certain range of services might also be necessary for expressive people to express their personality in banking. More expressive people might value customer service experience higher concerning their choice. They could be more engaged with service quality and digital banking innovations. It could also be reasonable that more expressive customers value professional expertise higher, being more critical of the necessary competence of service personnel. In this regard, market mavenism is a related influencing factor. Market mavenism characterizes people "who have information about many types of products, shopping opportunities, and other facets of the market, initiate conversations with other consumers and respond to information requests from other consumers" (Feick \& Price, 1987, p. 83). Hence, market mavens constitute a reference group with high expertise (Solomon et al., 2013). In this regard, we argue that more market-affine people could be more likely to choose a traditional provider type as these have a higher level of maturity. Since market mavens try to cover the market more and extend their knowledge greatly (Feick \& Price, 1987), we suppose that they might also be more interested in a higher scope of services than non-mavens. Customers familiar with the market might know more about the banking innovations of individual providers and evaluate them either more positively or more critically. It is also reasonable that market mavens place more value on professional competence. Furthermore, subjective norms point to the similarity of offerings to the customer, social environments, and the corresponding norms (i.e., situational normality). People who value situational normality higher could also prefer more traditional banking modes as these still constitute the norm. Therefore, we hypothesize that social conditions have a moderating influence on consumer choice (H-SOC) to positively influence the preference of traditional service attribute levels.

Attitudinal conditions We further analyze attitudinal conditions resulting from attitudes towards the particular stimuli under consideration, such as perceived usefulness (Davis, 1989) and perceptual affinity (Bruyn \& Lilien, 2008). People could be rather pragmatic or rather value-oriented to specific banking products and services. The perceived usefulness construct can be traced back to the technology acceptance model (Davis, 1989; Lee, 2009; Okazaki \& Mendez, 2013). Customers are likely weighing up which product is more practical, looking at their preferable checking account's functionality and task fulfillment. For the pragmatic, usefulness-oriented segment, this could mean that a specific provider type plays a significant role. The compatibility of consumer values is another aspect in forming attitudes that could impact banking account choice (Pousttchi and Dehnert, 2018). The perceptual affinity construct measures the degree to which recipients and informants are similar in values and experiences, especially in a world of increasing digital interactions (Bruyn \& Lilien, 2008). The condition describes the value orientation that points to the perceptual or emotional similarity with the service offering. We presume that perceptual affinity could impact the customer service experience and digital product innovation positively. In turn, value orientation could also positively impact traditional service attributes such as the bank provider type or human customer advisory. Therefore, we hypothesize that attitudinal conditions have a moderating influence on consumer choice (H-ATT) to positively influence the preference of specific traditional and digital service attribute levels.

Controls We include additional control variables to explain possible differences in consumer choices, such as the consumption-based experience of loyalty (i.e., prior checking 
account switching behavior), education, or age. Loyalty could play a considerable role in customer relationships for digital banking. Less loyal customers might especially be more open to other types of providers than the traditional bank. Personal characteristics, such as age, education, and gender, might also influence CDM in digital banking. We expect that older people might prefer a traditional bank because it might be thought of as a symbol of trust and heritage (Almquist et al., 2016). People might be especially more traditionally oriented for higher age groups. It is reasonable that the propensity for a higher scope of service increases with age. On the contrary, older people might not be keen on digital AI-based banking products but prefer higher professional expertise, such as a human customer advisor. Accordingly, we conducted additional analyses on the moderating influence of education (degree) and gender. Personal distress is included to measure the degree of ambiguity, uncertainty, or stress the participants perceive in CDM.

Figure 1 shows the final research model with the direct effects and the interaction of choice attributes and influencing factors on choice.

\section{Methodology}

Our research approach follows three major steps. After developing our research model, the survey, data collection strategies, and instruments were developed. We analyzed the data with SmartPLS 3.32, including structural and measurement model checks. We conducted flexible mixture modeling in "Flexmix" in R, a general framework for finite mixtures of regression models using an expectation maximization procedure. In the following, we describe our survey design, data collection, and data analysis strategy in detail.

\section{Survey design}

The survey questionnaire entailed three parts. After the initial demographic questions and initial construct measurement, the second part was the discrete choice experiment with eight choice sets through which each participant was guided. An introductory text explained what a traditional bank and a Fintech are and the further experiment procedure to sharpen participants' awareness. We added an introductory page explaining the experiment. Before experimenting, participants were familiarized with the study using ex-ante explanations: A decision should be made about the primary checking account. A listing of bank types and potential representatives followed for traditional banks (e.g., savings banks, cooperative banks) and Fintech (e.g., N26, Apple, Google), plus the explanation of the experiment with an example.

We decided to follow a complete full factorial $2^{5}$ discrete choice model from the literature (Street \& Burgess, 2007), leading to eight choice sets each participant must choose on. Accordingly, eight choice sets were built systematically using an established choice experiment design software. We included our five service attributes for checking accounts with two levels each to preserve the orthogonality of the experimental design (Kuhfeld et al., 1994; Naous \& Legner, 2020; Street \& Burgess,

Fig. 1 Research model

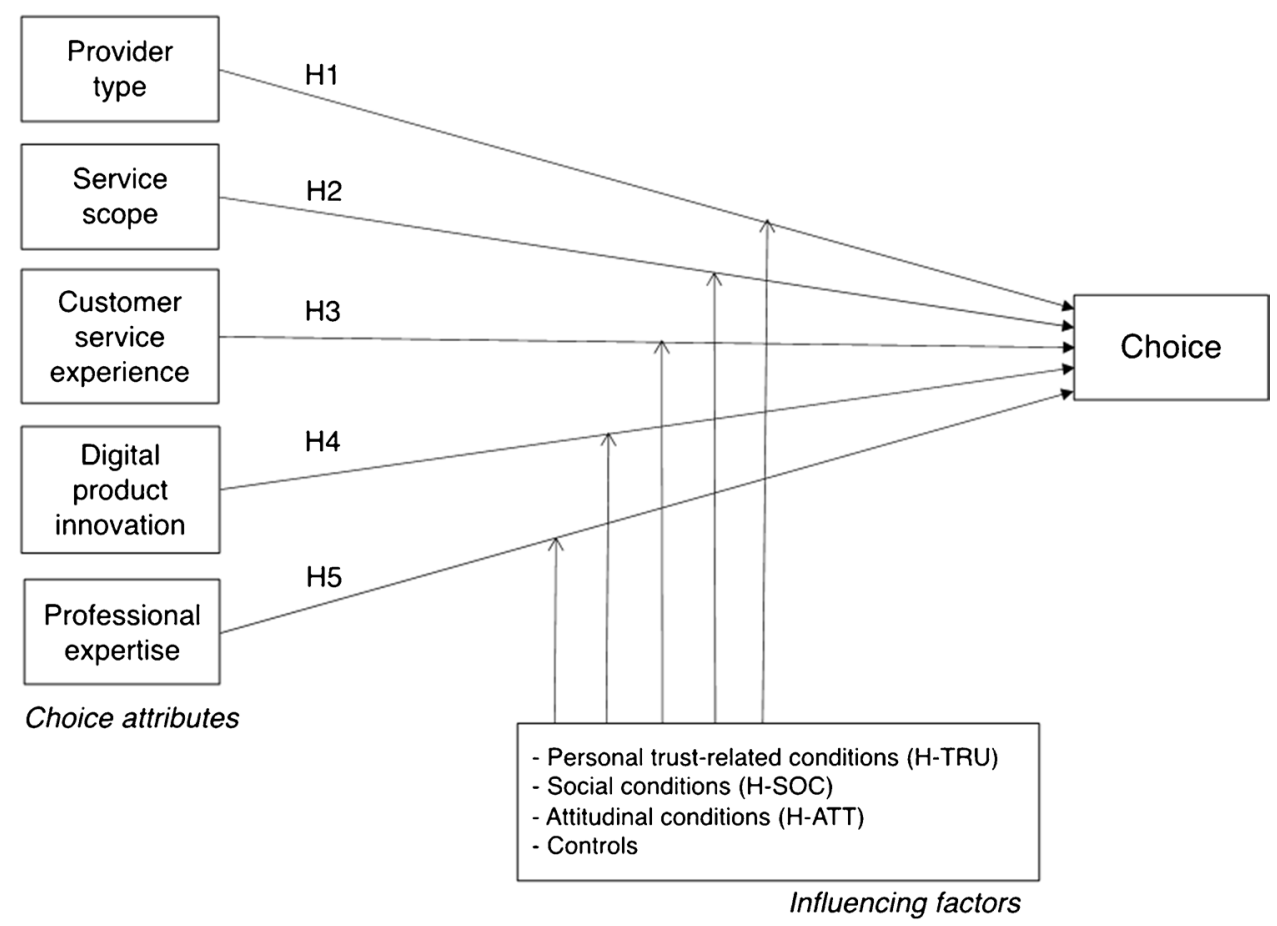


Fig. 2 Exemplary choice set (translated)

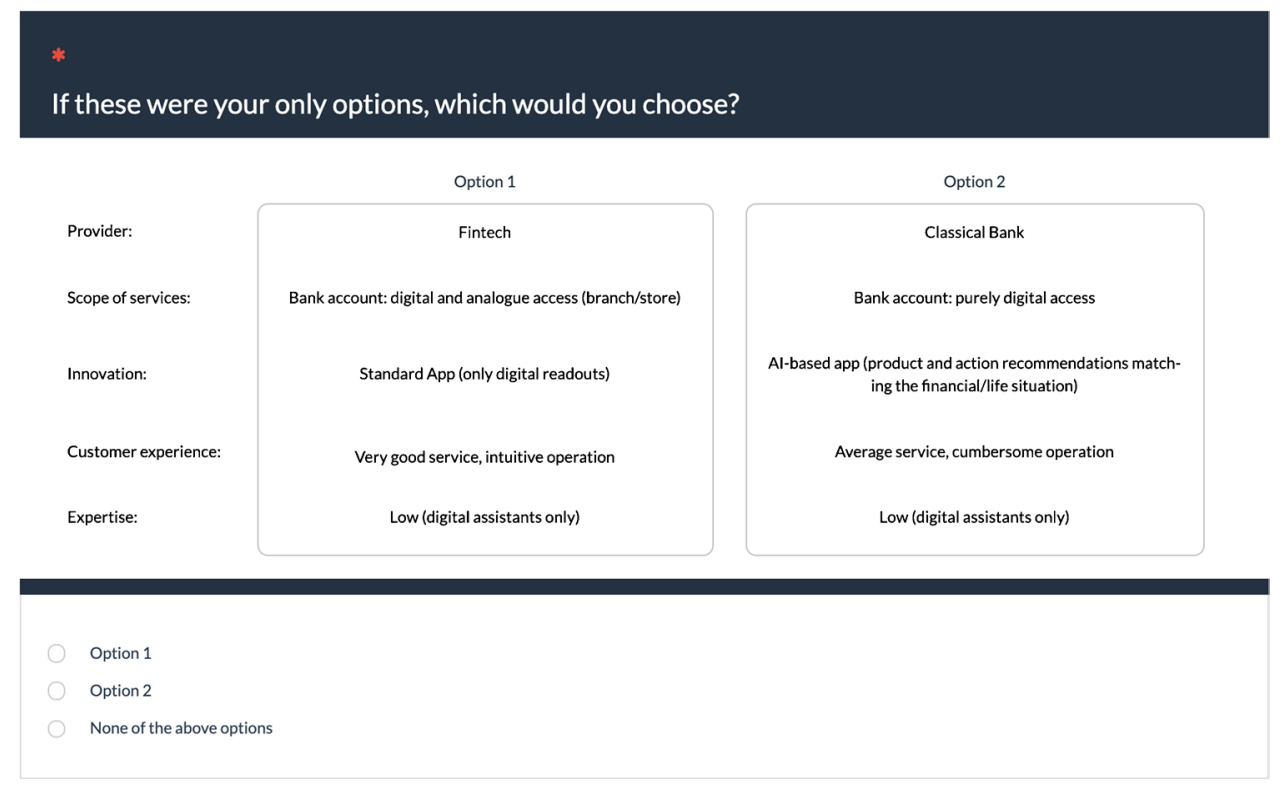

2007). Each participant had to rate all the choice sets so we could conduct the multigroup analysis. Thus, block building was avoided. An exemplary choice set is depicted in Fig. 2.

Each participant went through the randomized eight choice sets having three options: Choosing option 1, option 2 , or a 'none' option. In case the participant took an option, this choice option became " 1 ," otherwise " 0 ," and both options in a choice were set at " 0 " in the case of choosing the 'none' option. Thus, each participant has implicitly made 16 decisions.

The third part of the survey included further questions on CDM influencing factors afterward. With this, we collected data on the remaining influencing factors. We did not measure the latent variables after each choice specifically but asked the respondents about the overall impact of different aspects on their decisions. These questions included a questionnaire with 6-point Likert scales ranging from "Do not agree at all" to "Totally agree." The constructs were measured reflectively. The questions are based on scales from the relevant literature (see Sect. 2). We used a single item for loyalty, age, gender, and education (degree). The construct items are listed in the appendix. All questions relevant to the evaluation were mandatory.

We conducted a pre-test with university students collecting over 50 responses to test comprehensibility and then solicited comments and suggestions for improvement via a free text field. Overall, the participants confirmed that they understood the experiment and felt their CDM process had been adequately considered.

\section{Data collection}

Our data were collected using the developed anonymous survey conducted with a German market research firm in summer 2020. The data collection entailed an online panel in a cross-sectional sample of adult customers with 992 valid participants. Additionally, we placed a short announcement of our online experiment in a major German financial magazine ("Finanztest") to reach more offline participants, with 205 valid responses. Participants with short processing times were excluded ex-post. We removed 34 implausible responses from the online panel and four responses from the magazine. Overall, we evaluated 1197 valid responses. We checked the overall results and compositional invariance for both groups afterward but did not identify remarkable differences. The participants had the possibility of determining time and place independently. Since the participants were not observed directly, social desirability bias can be regarded as low. Another measure to reduce bias was randomizing the question order, such as the sequence of choice sets. The scales in the survey questionnaire were generally kept consistent to avoid common method bias (Podsakoff et al., 2003). The sample demographics distribution is depicted in Table 1. Due to the balanced sample and the orthogonal experiment design, it is possible to derive more detailed statements about the preferences of the subgroups. The participants are relatively evenly distributed among the different age groups and slightly predominant among the 30-to 39-year-old people. There was a slight surplus of survey participants without a university degree, the same for the male gender.

\section{Data analysis}

We used partial least squares structural equation modeling (PLS-SEM) and finite mixture modeling (Flexmix) to estimate the effects. The analysis of discrete choice data in PLS-SEM is based on linear probability models (Hair et al., 
Table 1 Sample demographics $(n=1197)$

\begin{tabular}{ll}
\hline Age & \\
\hline $18-20$ & $0.6 \%$ \\
$21-29$ & $16.2 \%$ \\
$30-39$ & $32.0 \%$ \\
$40-49$ & $18.1 \%$ \\
$50-59$ & $22.6 \%$ \\
Above 60 & $10.4 \%$ \\
Education & \\
Lower secondary school graduates or equivalent qualification & $6.3 \%$ \\
Secondary school certificate or equivalent qualification & $23.3 \%$ \\
Advanced technical college entrance qualification or equiva- & $8.8 \%$ \\
lent & \\
A-levels or equivalent & $16.3 \%$ \\
Ungraduated university studies & $3.3 \%$ \\
Bachelor's degree & $16.8 \%$ \\
Master's degree & $22.8 \%$ \\
Doctoral degree & $2.4 \%$ \\
Gender & \\
Male & $56.2 \%$ \\
Female & $43.8 \%$ \\
\hline
\end{tabular}

2019; Naous \& Legner, 2020). We chose this novel analysis approach to conduct multigroup analysis for moderation effects. The estimated regression coefficients correspond to the utility values of a service attribute (i.e., partworths) on our binary dependent variable, "choice." The coefficients finally represent relative instead of absolute influences on choice. The orthogonal experimental design causes the values for attribute levels to differ in their magnitude ("-1"). For instance, if the attribute level "traditional bank" is positively valued with a coefficient of " 0.2 ", the "Fintech" attribute level would be precisely orthogonal and valued at "-0.2."

We first used the discrete choice data and estimated the direct effects using the PLS-SEM algorithm, bootstrapping with 5000 samples. As expected, the results for the path coefficients of the service attributes were identical for PLSSEM and Flexmix.

Next, we elaborated on the observed heterogeneity in PLS-SEM, i.e., the influence of the surveyed latent characteristics of the experiment participants on the weighting of their preferred choice attributes (Hair et al., 2018). A conventional moderator analysis is not recommended for continuous independent and binary dependent variables in PLS-SEM (Bodoff \& Ho, 2016). However, a comparative multi-group analysis is possible for binary target variables, and we can create these groups using the latent variables. We used the PLS-SEM multi-group analyses, i.e., PLS-MGA and permutation procedures (Hair et al., 2018). Hence, subpopulation samples are analyzed as separate groups, and the significance levels of the group differences are estimated afterward (Henseler, 2012). PLS-SEM comes into its own here since we can calculate the regression coefficients and determine the significance levels for group differences by bootstrapping, which is a pragmatic approach for a moderation analysis. We took the center value of our 6-point Likert scales as the differentiation criterion for the membership into a low or high group and the lower and upper boundaries "2" and "5" for very low and very high group memberships.

PLS-SEM currently does not support the analysis of unobserved heterogeneity with aggregated choice data. Therefore, we performed the latent class regression analysis in R. The Flexmix package was used to segment the data by assigning each participant observation to latent classes to derive divergent CDM clusters. Finite mixture models are estimated with a maximum likelihood estimator and the expectation-maximization (EM) algorithm (Leisch, 2004). We integrated the binary service attributes and the construct score values for the influencing factors, calculated in SmartPLS, for hybrid choice modeling (Louviere et al., 2008). For estimation, we used a method known as the "joint approach" that produces less error in latent class segmentation (Andrews \& Currim, 2003). The method is implemented in Flexmix as the "concomitant variable model" with two parts (Grün \& Leisch, 2008). The variables in the regression model influence the dependent variable, choice, while the influencing factors in the concomitant variable model explain the segment affiliations (sizes). While the choice model can be estimated with the binary service attributes, the Likert scaled influencing factor data must be estimated as a multinomial logit model. The procedure then involved a parameter estimation in maximizing the log-likelihood values. This procedure delivered the path coefficients for the binary service attributes on choice. The influences of the latent personal characteristics on the various segments were determined in the multinomial logit model. For this purpose, we have set the largest segment as the baseline. The coefficients show the change in log odds when one predictor changes by one unit, holding all other predictors constant. In principle, their interpretation is identical to multiple linear regression coefficients. The significance of the results was tested in Flexmix by bootstrapping and log-likelihood tests (Train, 2009). We checked for identifiability problems by comparing the bootstrapped results for different numbers of segments (Dolnicar \& Leisch, 2010; Leisch, 2004). While minimizing the Akaike and Bayesian Information Criterion and log-likelihood values, the derived assignments became a stable compromise of segment size, empirical explanatory value, and model quality leading to a six-segment solution (Hair et al., 2018). Here, we found the highest practical explanatory value and theoretical generalizability. For bootstrapping with 1000 samples, the likelihood ratio test was passed with a $p$-value of 0.026 . The segment assignments remained stable; however, the regressors varied slightly due 
to the probabilistic nature of the expectation-maximization algorithm.

\section{Construct evaluation}

The construct evaluation includes reliability and discriminant validity tests (Hair et al., 2014). The PLS-SEM literature recommends using composite reliability. The constructs' composite reliability values are above 0.7 and below 0.9 , as recommended in the literature. The PLS-SEM calculation of Cronbach's alpha is sensitive to the number of items, underestimating alpha (Hair et al., 2014). A minimum alpha value of 0.5 is recommended for constructs with two indicators, 0.6 for three and 0.7 for four or more indicators (Ohlwein, 1999, p. 224). All constructs met this requirement. The outer loadings are all well above the recommended value of 0.708 for the reflective constructs. The average variance extracted (AVE) is also well above the recommended minimum value of 0.5 (Hair et al., 2014). Thus, the constructs show no issues regarding composite and convergent reliability. The results are listed in Table 2.

Regarding discriminant validity, the Fornell-Larcker criterion was satisfied. The heterotrait-monotrait ratio of correlations (HTMT) indicated that the importance of trust and calculative-based beliefs on the one hand and expressiveness and market mavenism on the other was perceived somewhat similarly by respondents as they show slightly higher HTMT values than recommended in the literature. Accordingly, it can be assumed that these constructs show similar effects on choice, which is not an issue for our purpose of analysis as they were assigned to the same respective group of conditions. The collinearity statistics with the variance inflation factor showed values below 2 and a single value of 3.5, which is still below the recommended threshold of 5 (Hair et al., 2011). We also checked the configural and compositional invariance of the constructs for the multigroup analysis (Hair et al., 2018), with no identifiable issues. The results are listed in Tables 6, 7, 8 and 9 in the appendix.

Table 2 Construct validity and reliability

\begin{tabular}{llrll}
\hline Construct & $\begin{array}{l}\text { Cronbach's } \\
\text { Alpha }\end{array}$ & rho_A & $\begin{array}{l}\text { Composite } \\
\text { Reliability }\end{array}$ & AVE \\
\hline Importance of trust & 0.822 & 0.826 & 0.894 & 0.738 \\
Calculative based beliefs & 0.756 & 0.759 & 0.891 & 0.804 \\
Structural assurances & 0.846 & 0.852 & 0.907 & 0.764 \\
Expressiveness & 0.835 & 0.978 & 0.893 & 0.738 \\
Market mavenism & 0.894 & 0.931 & 0.933 & 0.823 \\
Situational normality & 0.619 & 0.831 & 0.825 & 0.705 \\
Perceived usefulness & 0.880 & 0.881 & 0.926 & 0.807 \\
Perceptual affinity & 0.806 & 0.821 & 0.872 & 0.632 \\
Personal distress & 0.886 & 28.143 & 0.902 & 0.824 \\
\hline
\end{tabular}

\section{Results}

In the following, we examine the direct and moderating effects of the influencing factors on choice and derive the latent segmentation results. We have chosen the typical configuration of a traditional universal bank as the reference point in the results section (see Table 3 , left column). The utility values for the respective contrary (i.e., typically digital) attribute levels are orthogonal.

\section{Direct effects}

Firstly, we describe the overall results of the direct effects. Table 3 presents the results for the total sample.

The overall direct effects show that the average survey respondent was rather traditionally oriented towards checking accounts. The average customer still prefers a traditional bank, the possibility of both digital and a branch or store service, as well as appreciates a high customer service experience, a standard mobile app, and the possibility to contact a personal advisor. While all direct regression paths are significant, we found that the provider type (0.042) and digital product innovation (0.023) are way less decisive service attributes compared to customer service experience $(0.280)$, professional expertise $(0.210)$ and the scope of services (0.186).

The latter factors influence customer choice more strongly. Although the average participant in the crosssectional sample slightly tends to favor a traditional bank, the customer service experience of the provider is ultimately seven times more important to them than the provider type. A high level of professional expertise is about ten times more decisive criteria than digital product innovation. These results highlight that, on average, checking accounts are evaluated primarily based on customer service experience, service scope, and human professional expertise. Accordingly, digital product innovation, on average, is only a means to an end in CDM. However, our findings indicate that all service attributes still significantly impact the choice of checking accounts. Hence, we support $H 1$ to $H 5$. An additional analysis of the observed and unobserved

Table 3 Overall direct effects (total sample)

\begin{tabular}{ll}
\hline DV: Choice & Path coefficient \\
\hline Provider type ("traditional bank") & $0.042^{* * *}$ \\
Scope of services ("both digital and branch/store") & $0.186^{* * *}$ \\
Customer service experience ("high") & $0.280^{* * *}$ \\
Digital product innovation ("standard app") & $0.023^{* * *}$ \\
Professional expertise ("human customer advisor") & $0.210^{* * *}$ \\
\hline
\end{tabular}

(Significance level: *** $p<0.001, * * p<0.01, * p<0.05$ ). 


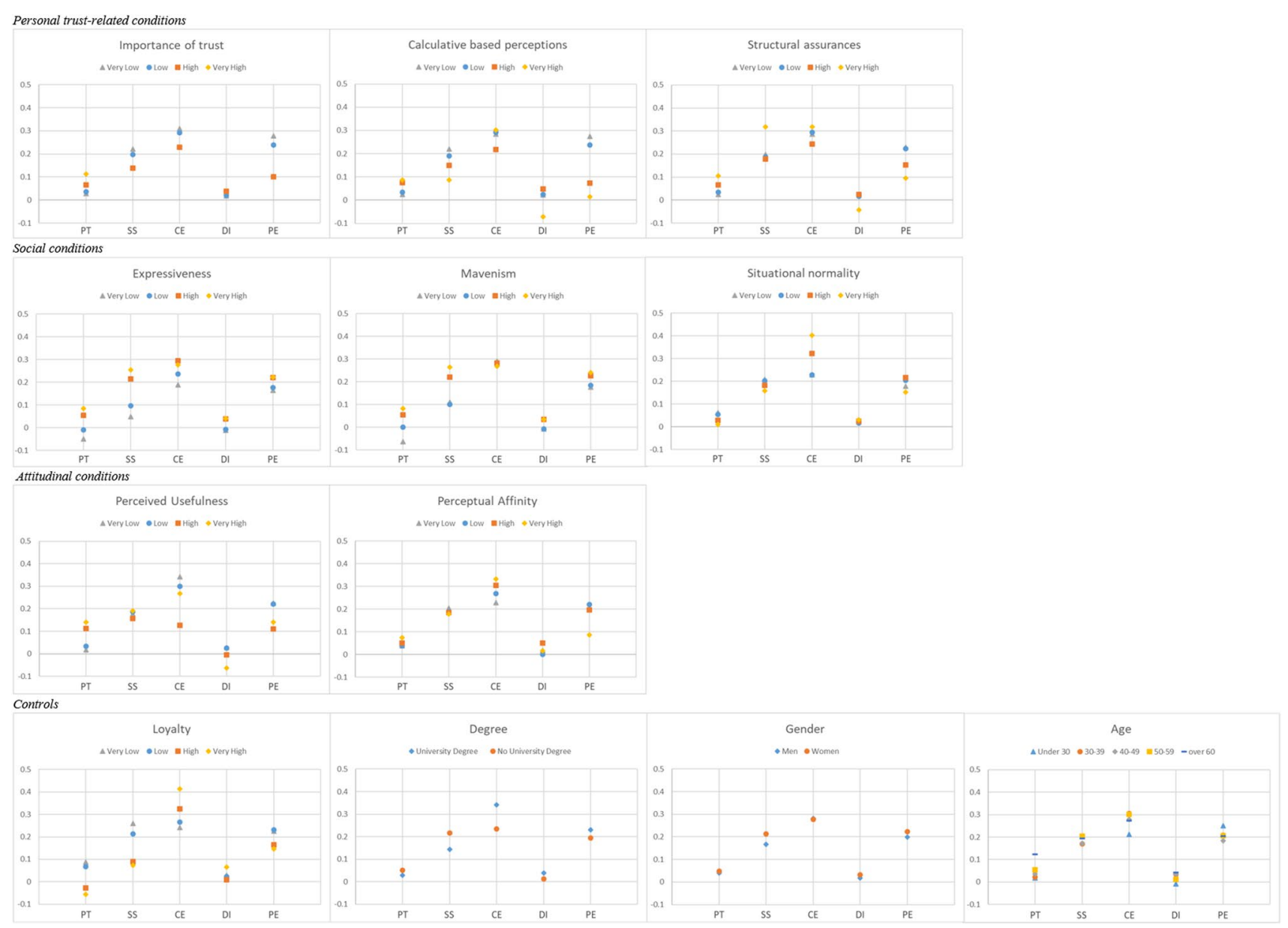

Fig. 3 Results for the observed heterogeneities (influencing factors). $P T=$ Provider type ("traditional bank"), SS=Service scope ("digital and analogue access"), CE=Customer service experience ("high"),

heterogeneities is vital to identify the moderating impact of the influencing factors and the underlying customer segments for checking account choice.

\section{Moderating effects}

Secondly, we present the results of the multigroup analyses on the observed heterogeneities, i.e., the interaction of the influencing factors with the service attributes on choice. Figure 3 summarizes the results graphically with coefficient plots. The tables for the multigroup analyses can be found in the appendix.

\section{Personal trust-related conditions}

The majority of participants with low importance of trust emphasized the service scope, customer service experience, and human customer advisor in their choices. These results differed for the more trust-sensitive participants
$D I=$ Digital product innovation ("standard app"), PE=Professional expertise ("human customer advisor")

who weighted the traditional bank as the provider even above the human customer advisor. The results for calculative-based beliefs reveal a similar picture with slight differences on the periphery. People with such trust perceptions put less emphasis on the traditional branch-based operating model or a human customer advisor. They would prefer a traditional bank and AI-based mobile app $(-0.072)$ even more. Our analysis thus reveals that traditional banks are chosen if a customer values or perceives trust intensely. Moreover, choosing digital product innovations also requires trust perceptions. People who perceived structural assurances in CDM were more likely to choose a traditional bank as the provider and more prone to the traditionally high service scope. Hence, branches can be considered contributors to structural assurances. Overall, our results indicate that trust beliefs have a moderating influence on choice. We support H-TRU due to the identified significant group differences. Table 10 in the appendix shows the results of the multigroup analysis for H-TRU. 


\section{Social conditions}

Regarding social conditions, the majority of participants reported being among the more expressive and knowledgeable customers. We found that more expressive and experienced customers value a traditional bank as the provider and high service scope, indicating a strong imprint of the traditional operating model. At the lower end of the expressiveness spectrum, people slightly preferred a Fintech as the provider $(-0.049)$ but were still indefinite about the level of digital product innovation. The traditional bank provider type, a high scope of services, and a human customer advisor is essential for the high maven group, regardless of the consistently high value of customer service experience. Thus, digital banking innovations surprisingly play more of a subordinate role for both mavens and non-mavens. The high norm group gives customer service experience also a higher priority. We found significant changes in the segments, supporting H-SOC. Table 11 summarizes the results of the multigroup analysis for H-SOC.

\section{Attitudinal conditions}

We further observe the impact of attitudinal conditions on CDM. Regarding perceived usefulness, a pragmatic customer has a higher preference for the traditional bank as the provider type, a lower customer service experience orientation, and a lower affinity towards a human customer advisor. Both the high and low segments do not put much emphasis on digital product innovation. However, the very pragmatic users would favor an AI-based mobile app (-0.064) in managing their personal finances. For perceptual affinity, we found less apparent changes in CDM. The more perceptually oriented consumers emphasize customer service experience even more. Surprisingly, human customer advisors are significantly less important for the very perceptually affine consumers than for the non-affine users. Still, the focus remains on traditional product categories across these segments. The influencing factors are less impactful than expected, as perceptual affinity primarily affects the peripheral groups. We support H-ATT based on the identified significant group differences. Table 12 shows the results of the multigroup analysis for H-ATT.

\section{Controls}

Other aspects of CDM have been considered as controls, such as loyalty, gender, or age. A majority of the participants claimed to be less loyal customers. The very loyal customers would consider a Fintech $(-0.057)$ as the provider type than their peers. The analysis on degree revealed that the more educated people value customer service experience even more than people without a university degree. However, these participants showed significantly less demand for a traditional branch-based operating model (but still do). Regarding gender, we found only very few group differences. A broad service scope including branches was a bit more important to women than men. It became clear that with increasing age, people favor a traditional bank as the provider type; this was particularly significant for the over 59-year-olds. Accordingly, our data show that customer service experience is more important for older people. Surprisingly the younger participants are only slightly more digitally affine than their older peers. We also find it interesting that the younger participants show a slightly higher demand for a human customer advisor. For reasons of space, we have not included the coefficient plots for distress in CDM. Table 13 in the appendix exhibits the results of the multigroup analysis for the controls.

\section{Latent class segmentation}

Thirdly, we present the results for the analysis of unobserved heterogeneities, including six latent customer segments. Table 4 shows the segmentation results sorted by descending segment size. The segments are designated according to their characteristic service attributes. Table 5 shows the multinomial logit model results for the impact of the influencing factors on the segment assignments compared to the baseline.

The first and largest cluster differentiates the "traditional product-innovative segment" of customers that prefer a traditional but digitalized operating model. This segment favors traditional banks as their provider but would prefer a more digital product offering and is thus open to data-driven, innovative banking applications. These customers do not (over-) emphasize customer service experience compared to the overall results. They still value the opportunity to visit a branch and prefer a "human" touch of banking, including the possibility of contacting a human customer advisor. The analyses show that this segment primarily entails usefulnessoriented, middle and higher-aged customers compared with the other segments.

The second solution shows the "advisory-focused segment" of customers with a low propensity for digital product innovation and a strong focus on the human aspects in banking, i.e., customer advisors. These customers, surprisingly, would also be inclined towards alternative offerings of Fintech. Moreover, the customer service experience is essential to customers in this segment. Accordingly, a standard app would be sufficient for them. They attach the least importance to bank branches among the attributes. These customers are less concerned with trust than the baseline, younger than those in the largest segment, and more oriented towards 
Table 4 Identified segments in the latent class regression analysis

\begin{tabular}{|c|c|c|c|c|c|c|}
\hline DV: Choice & $\begin{array}{l}\text { Segment } 1 \\
\text { "Traditional } \\
\text { product-inno- } \\
\text { vative } \\
\text { segment" }\end{array}$ & $\begin{array}{l}\text { Segment } 2 \\
\text { "Advisory- } \\
\text { focused seg- } \\
\text { ment" }\end{array}$ & $\begin{array}{l}\text { Segment } 3 \\
\text { "Direct bank- } \\
\text { ing segment" }\end{array}$ & $\begin{array}{l}\text { Segment } 4 \\
\text { "Fintech seg- } \\
\text { ment" }\end{array}$ & $\begin{array}{l}\text { Segment } 5 \\
\text { "Experience- } \\
\text { focused seg- } \\
\text { ment" }\end{array}$ & $\begin{array}{l}\text { Segment } 6 \\
\text { "Branch- } \\
\text { focused seg- } \\
\text { ment" }\end{array}$ \\
\hline Provider type ("traditional bank") & $0.203 * * *$ & $-0.123 * * *$ & 0.006 & $-0.219 * * *$ & 0.022 & $0.143 * * *$ \\
\hline $\begin{array}{l}\text { Scope of services ("both digital and } \\
\text { branch/store") }\end{array}$ & $0.270 * * *$ & $0.080 * * *$ & $-0.158 * * *$ & $-0.051 * *$ & $0.226 * * *$ & $0.742 * * *$ \\
\hline Customer service experience ("high") & $0.174 * * *$ & $0.324 * * *$ & 0.012 & $0.485 * * *$ & $0.750 * * *$ & $0.174 * * *$ \\
\hline $\begin{array}{l}\text { Digital product innovation } \\
\text { ("standard app") }\end{array}$ & $-0.124 * * *$ & $0.189 * * *$ & $0.272 * *$ & $-0.329 * * *$ & $0.200 * * *$ & $0.056^{* * *}$ \\
\hline $\begin{array}{l}\text { Professional expertise } \\
\text { ("human customer advisor") }\end{array}$ & $0.243 * * *$ & $0.561 * * *$ & -0.001 & -0.028 & $0.211 * * *$ & $0.046^{* *}$ \\
\hline Segment size (share) & $416(33.7 \%)$ & $220(17.8 \%)$ & $165(14.6 \%)$ & $134(11.3 \%)$ & $133(11.3 \%)$ & $129(11.3 \%)$ \\
\hline
\end{tabular}

(Significance level: $* * * p<0.001, * * p<0.01, * p<0.05$ ).

Table 5 Multinomial logit model results

\begin{tabular}{|c|c|c|c|c|c|}
\hline DV: Choice & $\begin{array}{l}\text { Segment } 2 \\
\text { "Advisory- } \\
\text { focused seg- } \\
\text { ment" }\end{array}$ & $\begin{array}{l}\text { Segment } 3 \\
\text { "Direct } \\
\text { banking seg- } \\
\text { ment" }\end{array}$ & $\begin{array}{l}\text { Segment } 4 \\
\text { "Fintech segment" }\end{array}$ & $\begin{array}{l}\text { Segment } 5 \\
\text { "Experience- } \\
\text { focused seg- } \\
\text { ment" }\end{array}$ & $\begin{array}{l}\text { Segment } 6 \\
\text { "Branch- } \\
\text { focused seg- } \\
\text { ment" }\end{array}$ \\
\hline Importance of trust & -0.212 & $0.539 * * *$ & $0.280 *$ & -0.110 & 0.152 \\
\hline Calculative beliefs & $-0.330^{\dagger}$ & 0.263 & 0.256 & 0.091 & 0.185 \\
\hline Structural assurances & -0.043 & -0.076 & -0.202 & -0.010 & -0.196 \\
\hline Expressiveness & -0.135 & -0.002 & -0.112 & -0.006 & 0.062 \\
\hline Market mavenism & 0.125 & $-0.327 *$ & -0.220 & -0.130 & 0.022 \\
\hline Situational normality & $0.175^{*}$ & -0.075 & $0.224 *$ & 0.076 & -0.033 \\
\hline Perceived usefulness & -0.168 & $-0.260^{\dagger}$ & $-0.597 * * *$ & $-0.624 * * *$ & 0.001 \\
\hline Perceptual affinity & $0.264 *$ & 0.214 & 0.187 & $0.564 * * *$ & 0.062 \\
\hline Loyalty & 0.044 & $0.205^{*}$ & 0.308*** & $0.284 * * *$ & -0.055 \\
\hline Age & $-0.203^{*}$ & -0.123 & $-0.338 * *$ & -0.114 & -0.135 \\
\hline Gender & 0.286 & 0.121 & 0.037 & -0.138 & -0.178 \\
\hline Education & $0.105^{*}$ & -0.083 & 0.004 & $0.151 * *$ & $-0.131 *$ \\
\hline Distress in CDM & 0.017 & $-0.192 *$ & $0.207 *$ & -0.132 & 0.109 \\
\hline
\end{tabular}

(Significance level: $* * * p<0.001, * * p<0.01, * p<0.05,{ }^{\dagger} p<0.10$ ). subjective norms (i.e., situational normality). They come from a higher educational background and have a greater perceptual affinity for values that are primarily oriented towards traditional banking expertise.

The third "direct banking segment" shows a very pragmatic attitude towards banking. These customers prefer purely digital access to their checking accounts and want to manage their finances without human customer advisors (but are also not inclined to digital assistants). Standard app functionalities are also sufficient for this customer segment. Both the provider type and the customer service experience are irrelevant choice criteria. Thus, direct bank customers are, in principle, open to both types of providers. These customers are typically less frequent bank switchers than the baseline customers. We found higher importance of trust compared with the traditional product-innovative customers. Direct banking customers are less likely to be market mavens than customers in the largest segment.

We further identified a fourth "Fintech segment" that entails customers who value a purely digital checking account. They consciously choose a Fintech provider, demand advanced AI-based digital product innovations, and prefer to do their banking digitally without branches and human customer advisors. However, the outstanding attribute for this customer segment is the intense focus on the customer service experience, which is expressed in the digital realm. Still surprisingly, this segment is also relatively small, reflecting the market share of these providers in Germany. 
Fintech customers are also more trust-oriented than traditional bank customers, presumably as they prefer novel market offerings. This customer segment clearly entails the youngest customers among the segments. They perceive CDM situations as more stressful than their peers. Their decisions are less pragmatic, i.e., not as usefulness-oriented as those of traditional product-innovative customers. They may value playfulness, ease of use, and perceived enjoyment. In addition, these young customers are significantly more oriented towards their environment and the prevailing social norms. Interestingly, they tend to have less detailed knowledge of the market from their perception, although this was barely not significant. These customers do not count themselves as frequent product switchers, maybe as many of them could be rather new to banking.

The fifth "experience-focused segment" suggests that the customer service experience is paramount to these customers. They value seamless operations without interferences or malfunctions. Yet, the remaining traditional attributes, such as bank branches and personal customer advisors, are also crucial for them. These customers are not interested in digital product innovations. Thus, the customer service experience is primarily expressed in standard processes that may still involve human interactions. However, when it comes to the provider type, they are undecided and could principally be open to new market offerings. These customers have a higher level of education than the traditionally innovative customers. They are more loyal and value-oriented (perceptually affine) but less pragmatic than the customers from the baseline segment. This value orientation thus relates to traditional banking attributes such as a positive customer experience, including a personal human touch. Accordingly, private banking customers could be found among them.

Finally, the sixth "branch-focused segment" has a strong demand for traditional branch access to banking. Other than that, this segment is rather unremarkable. These customers prefer a traditional bank but are somewhat undecided about digital product innovations. Interestingly, however, the human customer advisor is not very important to this segment, so these customers are primarily interested in retaining on-site self-services. Customers in this segment come from a lower educational background compared to the traditional product-innovative customer segment.

From the path coefficients, we can draw inferences on CDM behavior. The results for the largest first segment indicate a very balanced CDM involving all service attributes. For segments two, four, five, and six, we can infer from the single high path coefficients that these customers are very focused on particular service attributes, i.e., human personal advisory for segment two, customer service experience for segments four and five, and branch operating model for segment six. Participants in segment three have focussed on the fulfillment of the digital operating model criterion.

\section{Discussion}

We conducted a discrete choice experiment to analyze the personal preferences for checking account services among German banking consumers.

All hypotheses on the direct effects are supported to impact choice significantly, with different strengths. The overall results show that the majority of participants opted for a traditional banking model. We can state: On average, customers prefer a modern digital service offering from a traditional bank that provides branches and human customer advisory (at least) on demand. We found that the customer service experience is the most important aspect for customers regarding their choice. Our results indicate that the average bank customer does not need fancy digital features per se but bases its choice more on a positive customer service experience. Regarding this, our results show how fatal increasing reports of technical problems at banks can be for customer retention and acquisition in almost all customer segments (Charette, 2020).

Our findings allow statements on the damping or strengthening moderating effect of the influencing factors on the service attribute preferences. Overall, we see that our conditions help explain customers' preferences towards digital properties of checking accounts to varying degrees.

Considering the role of the provider type, we gained the insight that the personal trust-related, social, and attitudinal influencing factors as well as age all have a positive (i.e., strengthening) influence on the traditional bank preference. People who strongly emphasize trust choose the traditional bank as provider type, which is a reasonable finding. However, we would have expected a more substantial influence. A key factor certainly is that customers assume that a traditional bank could be more likely to act in the customer's interests and be perceived as more reliable. Those customers also perceive structural assurances more strongly. We further found that social conditions have the greatest impact on this attribute, as mavens opt for a traditional bank while non-mavens prefer a Fintech as their provider type, given the perception of professional intelligence. Market experts favored traditional products, possibly reflecting traditions in the German banking market. Overall, the traditional bank still holds a heritage value as a safe harbor for money that attracts and builds trust with the oldest group of customers (and with the younger, more indecisive people).

Regarding the scope of services, we found that the more maven and expressive people value a broader service 
offering, including the possibility of accessing these services via non-digital ways. On the contrary, loyal customers tend to hold on to this form of customer access less, although the effect remains positive. Interestingly, the nonmaven and low expressive customers place the least value on a branch-based operating model. Apparently, they lack a strong connection to this traditional service attribute, being among the direct banking and Fintech customers.

In addition, customer service experience turned out to be even more important for older and more expressive customer segments, while there is a constantly strong overall influence from this attribute. The very loyal customers value this attribute by far the highest, whereas the social and the attitudinal conditions also have an effect but do not make a vast difference here. In contrast, the segment of the usefulness-oriented (i.e., pragmatic) users do value experience considerably less high. We have seen that this attribute will also involve analog personal interactions for four segments, whereas, for direct banking and Fintech customers, it will involve mostly digital interactions.

Remarkably, we also found that digital product innovation is not very decisive for people on average. Customers who strongly perceive structural assurances prefer innovative data-driven digital products. Furthermore, we found that a strong usefulness orientation can explain the choice of digital product innovations. Plus, age can explain innovative choices here, as the under 30 -year-olds tend to be a bit more open to digital innovation but remain somewhat indefinite. For customers in the largest segment, digital AI-based products are initially a companion factor, while for Fintech customers, they are a critical decision-making factor.

Consumer preferences for professional expertise typically could remain with human customer advisors for the primary checking account. Remarkably, those customers who strongly emphasized calculative-based beliefs were the most indecisive on human personal advisory. This finding is interesting as we could infer a lack of trust in banking customer advisors (and their benevolence). Also, a very high perception of structural assurances indicated that customers are more likely to dispense with the expertise attribute or pay less attention to it. Moreover, the market mavens, the expressive, highly educated, and (surprisingly) the younger customers would rely on the possibility of contacting a human customer advisor the most. We assume that the mavens are more familiar with the banking products and the necessary expertise behind the product. We have seen customers from the largest segment and the second higher educational segment opt for human advisory. They belong to the group of customers who might have more complex banking needs and might know more precisely what requirements they have of their checking account provider. We can infer that the preference of banking market expertise should not be equated with Fintech innovativeness.

All moderators considered individually could have led to strong preference shifts, but none of the influencing factors pushed the overall choice firmly into the digital realm. Overall, strong digital attribute preferences could not be adequately explained through the singular observation of observed heterogeneities. Quite contrary, the latent class segmentation analysis explained the participant memberships to the more digital segments. Our analysis revealed that four customer segments would prefer both branch-based and digital access to banking checking accounts, which points to our sample's predominantly traditionally-minded German customers. Here, our influencing factors also contributed to explaining the segment assignments.

We want to emphasize two further findings from the segmentation results. Firstly, the largest, rather traditionally oriented customer segment still prefers a high service scope. Nonetheless, a stronger propensity towards digital product innovations becomes evident for this customer segment. Hence, pragmatic customers are open to digital innovations for data-driven banking, which must coincide with a positive customer service experience. Secondly, a smaller segment was identified that opts for purely digital checking accounts from Fintech at the other end of the spectrum. Some Fintech advocates might have chosen these offerings out of sheer inexperience, as we found some indications on this. However, social aspects and a non-pragmatic attitude towards banking strongly influence the preference of Fintech checking accounts. In this regard, most of the younger Fintech customers have shown a significantly stronger orientation towards subjective norms than the traditional product-innovative bank customers. Hence, these customers are likely more aware of Fintech products in their daily lives, including everyday encounters with the peer group or the sheer urge to experience novelty. We could also imagine that one reason for the different choice patterns is a change of customer journeys, primarily in the digital realm, such as online communities or social media platforms. We highlight several implications for research and practice in the following.

\section{Conclusion}

\section{Implications for research}

This paper provides a novel perspective on the interactions between service attributes and latent customer preferences for CDM in banking. We used a novel research approach for conducting IS studies on consumer behavior. Random utility theory posits that consumer preferences 
generally are a good predictor of customer choices. The choice design followed strict requirements of a full factorial model with the service attributes derived from current practice developments. The results show a broad spectrum of customer preferences that adequately reflect the market. Our findings provide novel insights into the diffusion of banking innovations, especially regarding the role of the novel Fintech provider and digital product innovations (Alt \& Puschmann, 2012; Gomber et al., 2018). In particular, we extend prior studies on banking service choice (e.g., Iqbal et al., 2003; Matsuo et al., 2018; Verma et al., 2004). Almost 20 years later, our results support Verma et al. (2004) that traditional bank attributes such as human professional expertise still matter. However, the increasing demand for digitalized products and services becomes apparent for latent customer segments.

We enrich the discussion on the influencing factors on the choice of banking providers, with traditional banks enjoying some historical merit, especially among trust-sensitive customers (Ologeanu-Taddei \& Vitari, 2020). Our study also updates the Iqbal et al. (2003) results for choice preferences among social conditions. We discovered market mavens to be very prone to traditional banking attributes, while Iqbal et al. found that high e-familiarity online consumers seemed to be the least demanding consumers. Furthermore, our results confirm the findings by Matsuo et al. (2018), indicating that social influences such as market mavenism go hand in hand with a more conservative approach to banking. However, the traditional pragmatic customer segment makes very balanced decisions and is probably less prone to adapt these products solely for making new digital experiences. Our results also suggest the impact of a cultural value dimension on CDM in banking (Tam \& Oliveira, 2019). Perceptual affinity was not very informative as a moderator solely, however, it helps identify the more traditional experience- and expertise-focused customer segments. Although positively related, perceptual affinity did not significantly explain the participant assignment to the Fintech customer segment. Overall, our analysis shows that our latent influencing variables can still explain the assignment to customer segments, including more digital ones. Likewise, the moderation analysis showed several significant results but only partially explained a shift towards digital service attributes. Our quantitative analyses thus confirmed prior qualitative research (Pousttchi and Dehnert, 2018) that various latent personal characteristics influence preference formation in digital banking.

Our findings indicate that customer service experience plays a vital role for traditionally and digitally oriented customers, contributing to the research on service experience (Groth et al., 2019). Regarding this, we provide updated and more fine-grained results for the developments around Fintech. The Fintech segment demands digitalized service experiences and product innovations, pointing to embedded finance to attract these customers as early adopters (Alt et al., 2019; Chen et al., 2018; Nüesch et al., 2015). We expect these products to spread the market if they provide a positive customer service experience in the digital realm.

\section{Implications for practice}

Several practical implications can be derived from our results. Checking account providers must find an appropriate product-market fit in digitalization (Bloch, 1995). Particularly, the dialectics of traditional and digital bank service attributes must be resolved strategically. While many banks claim to preserve the status quo, the Fintech innovators instead claim that future banking will be purely digital. Our results indicate that the truth lies somewhere in between as the optimal or preferred level of digitalization differs between the identified latent customer segments. The results show that traditional service attributes, in which traditional banks are powerful, could remain relevant in the future - albeit with a different integration due to varying use frequencies. Related research also shows that adopting digital-only bank services could increase the total transaction volume of customers but keep the traditional primary banking transactions stable (Fang et al., 2021). Accordingly, the digital business offers new revenue potentials that traditional banks could leverage. Other scholars showed that maintaining a minimized stationary customer interface is helpful in the omnichannel to prevent declining transaction volumes among all channels (Zhou et al., 2020). Our results suggest that further resources should be invested in digital service offerings, particularly addressing the human-technology interface, to enable seamless banking operations and a more accurate allocation of specialist expertise to customer needs, especially for advisory services.

While the type of provider plays a subordinate role overall, banks still enjoy customers' historical merit here. In Germany, at least, digital Fintech offerings are primarily attractive for peripheral groups. In this regard, traditional banks should find ways to fulfill the identified digital expectations of the largest traditional product-innovative segment. Traditional banks need to score with a wellthought-out combination of traditional and digital service attributes. In addition to traditional values such as a broad service scope, digitalization should be pushed forward to improve the customer service experience and provide digital product innovations. The primary asset of traditional banks is still their professional expertise. This competency must be better played out with digital and non-digital advisory interfaces to the customer. Traditional banks must 
focus again on providing added values for customers with an affinity for advisory, which does not necessarily have to include in-branch consultations but can also be done digitally. Some of these customers may not be satisfied with the established advisory settings as they might even be open to Fintech providers. Customer advisory services may no longer be seen as trust builders after customers have been driven out of branches for years for cost reasons. While most customer-bank interactions can be carried out independently through self-service, video consultations could be offered to reduce branch network costs. Since customers still attribute a lot of value to stationary forms of banking, new operating models must be found to guarantee costefficient integration of banking offerings. In other words: Traditional banks can only try to instill the desired usage behavior for unprofitable customers through re-established customer relationships and increasingly shifting it towards digital channels. Notably, this is already the strategy of many banks, but both the customer affection and processual implementation of omnichannel customer interaction are lacking.

Traditional banks also need to focus on customers with a substantial experience focus as these are also potential switchers to Fintech. Such a strong customer service experience orientation could likely be the primary driver of Fintech adoption in the future, also from the traditional bank customer segment. Banks should focus on improving the frictional points of the customer interaction, which depend greatly on the bank's ability to control its operational business, such as legacy core banking. At the moment, traditional banks are poorly constituted to win Fintech customers back, as these customers seek the antithesis of traditional banking - innovative digital checking accounts. However, none of the Fintech neobanks offer advanced data analytics yet. One decisive factor here will be developing trustworthy digital innovations that fulfill these very digital-oriented customers' subjective norms.

From a traditional banks' perspective, one worrying aspect is that the customers who have switched their bank less often in the past, in particular, would consider a Fintech as the provider type. Thus, an openness to new providers can be observed among longstanding customers. Loyal customers also put less emphasis on the traditional branch-based operational model than their less loyal peers. Plus, they prefer a high customer experience and are comparatively less reliant on branches. Also, the direct banking customers are more loyal than the traditional product-innovative customer segment. Thus, traditional banks could face customer churn in the future. Thus, our findings are both an opportunity and a warning signal for traditional banks to enhance their products and services in the digital realm and find new ways to interact with customers personally.

From a Fintech perspective, one future path to consider is attributing their products and service more traditionally without neglecting their modern digital core to expand their market share beyond the niche. Fintech could be predestined to win customers from the direct banking segment. However, Fintech would have to demonstrate real professional expertise in banking to win more traditional customer segments, which could be realized via video consulting offerings. Thus, more substantial banking expertise would be needed to occupy additional customer segment shares. Fintech would have to build up stationary factors such as (pop-up) branches/stores to address the customer needs of the traditional product-innovative and the branch-focussed segments. However, this could probably be outside the scope of these digital-native providers.

Our results underscore that managing the digital and non-digital services continuum is a determining element of a traditional bank's future strategy. Digital product innovation is a differentiating factor for Fintech and traditional product-innovative customers, while probably primarily an accompanying factor to improve the customer service experience for at least three further customer segments. While Fintech customers demand a distinctive, purely digital offering in line with subjective norms, the traditional product-innovative customers still demand personal advisory and access to on-site branch services. Banks could aim to become fully digital but would thus have to demonstrate their existing competencies in a purely digital way. Hence, traditional banks should find the right balance between digital and non-digital services to underscore their traditional values, such as professional expertise. However, the number of physical touchpoints probably decreases as the generated value of each stationary touchpoint increases. Hence, cost-intense branch structures should only be maintained if these structures contribute to valuable transactions through personal advisory interactions. We find evidence for three segments that they could likely draw on branches for advisory purposes, but we only measured preferences and not actual transactions. Customer interaction should therefore be skillfully played via digital channels whenever possible to keep in touch with customers.

Furthermore, our results suggest that personal advisors could be of little value to attract direct banking and branchfocused customers, which is surprising for the latter. These customers with a self-service tendency showed no or only a slight preference for human advisory via digital or stationary channels. This insight underscores the complexity of selling higher-value products to specific retail banking customers, thus perpetuating the current dilemma to gain 
access to particular customer needs and wants as a primary house bank. Traditional universal banks will have to make the benefits or advantages of their monetizable products and services clearer to these customers who prefer standardized digital products and little human intervention. Banks could help the less-educated customers navigate more complex financial products to revive the primary house bank relationship. Precisely these branch-focused but rather advisory-averse customers could be encouraged on-site to increasingly switch to digital channels, using learning spillover effects (cf. Zhou et al., 2020). Regionally shared service centers or pop-up branches could be appropriate structures to address basic needs, such as access to stationary services, while reducing overall costs (King, 2019). Pop-up branches could greatly increase flexibility in managing supply and demand for brick-and-mortar services and thus improve the interaction with digital services. Another option is setting up cost-efficient transaction-oriented (direct) banks that could serve these customers.

Quite the contrary, individualized branch concepts could complement the standardized digital products and services to serve the experience- and advisory-focused customers. Mainly the experience-focused customers show echoes of higher-value private customer business as they place less value on pure usefulness but personal value fit. More niche, i.e., specialized and expertise-rich products and services could address these customer needs. The benefits of an onsite presence seem to shine through most clearly in this context, whereas standardized digital services can be helpful facilitators.

While only some customers prefer a purely digital user experience, most customers could likely switch between digital and non-digital channels or conclude a contract on-site after several digital interactions. Therefore, digitalized banks would provide omnichannel services with professional expertise across several channels, including the stationary one. The stationary channel could reinforce the digital interactions, just as these could be necessary to reinforce the physical touchpoints. In the future, customer behavior could be shaped through innovative digital and non-digital solutions towards more cost-efficient digital services. However, such a stepwise adaption towards the optimal digital service offering will not work for digitally underdeveloped paper-based banks. Thus, the digital transformation of banking structures demands corresponding digitalized processes, products, and revenue streams for increasingly digital customer interactions (Fang et al., 2021).

Beyond that, one possible future market scenario is bundling innovative digital services by a Fintech provider in cooperation with the operations of a traditional bank. This could eliminate the respective structural disadvantages by establishing open interfaces in financial market infrastructure (Alt \& Puschmann, 2012). Banks would become a trusted brand partner in the digital ecosystem business as they might not fulfill digital customer expectations themselves. Banks could generate additional revenues as a complementor of digital platform ecosystems on the one hand, along with the disadvantage of losing control of customer access and paying provisions on the other (Fang et al., 2021). In contrast, the ecosystem orchestrators could mediate stationary advisory services and the settlement of regulated banking products to its partnering banks. It could especially be possible for Fintech to win more trust-sensitive customers through such partnerships that combine the best of both worlds. Although Google has recently abandoned (or postponed) its "Plex" banking solution, the international market could likely be developing in this direction. Bigtech players could build partnerships with established banks, such as Apple and Goldman Sachs in the U.S. The relevance of such banking services for a customer likely depends on how mature its platform-based relationship with an ecosystem provider already is (Carbo-Valverde et al., 2020). Here, the future customer path to the checking account could lead via the digital services of Fintech or Bigtech, and not the other way around (Pousttchi and Dehnert, 2018).

\section{Limitations}

Despite its strengths, this study is not without limitations. Firstly, our stated preference experiment could not perfectly represent the market reality by its very nature. In selecting service attributes, we had to make trade-offs. We did, for instance, not work with brand names, so our results might not be one-to-one transferable to the GAFA banking world since greater brand attributions are expectable here. There was a low overall importance of trust in the hypothetical choice experiment, which could likely be higher for real choices. Although we have drawn on established scales, the relatively high proportion of expressive customers and market mavens is questionable. Our participants may perceive and know digital banking innovations and thus have consciously decided against them (as our results indicate), probably as they perceive them as still immature. Another possibility is that these services have not yet become sufficiently widespread in the German society, so they did not reach the participants' awareness (who assessed themselves as expressive and knowledgable despite their preference for traditional banking products). Here, our experiment's entry page provided a short market overview, but future studies could also survey market mavenism via a knowledge test. We also decided not 
to include price as a service attribute. Taking this into account would have led to a pricing study, which was not our goal. Pricing experts also state that bank customers' price sensitivity is low (Simon Kucher, 2019). Several studies show the abandonment of price attributes does not lead to an omitted variable bias (Pedersen et al., 2011). The order of other attribute preferences remains the same for unforced choices, including a 'none' option. However, we could have included perceived costs as a construct in the moderator analysis to explain better the choice of specific offerings such as direct banking. It would be exciting to investigate the willingness to pay for human advisory services, for example, by working with so-called "menus" in future choice experiments.

Secondly, the consumer research literature highlights that there can be problems related to studying personality traits (Solomon et al., 2013). Therefore, we selected influencing factors that we identified in a previous study based on consumer reviews and the prior literature as sufficiently valid, reliable, and actionable constructs to explain the impact of digitalization on CDM in banking (Pousttchi and Dehnert, 2018). However, situational factors can make a difference in CDM (Punj \& Stewart, 1983). The circumstances of the decision could bring changes, such as whether a customer is currently actively looking for a banking product or not. We have not been able to include or consider all these factors in this study. We included control variables of possible influences, such as loyalty, distress in $\mathrm{CDM}$, age, gender, or degree.

Thirdly, we did not measure real purchase decisions. Especially the moderating analyses showed the impact of the influencing factors across all choices, rather reflecting the consumers' consideration sets (Blackwell et al., 2002). The segment analyses, in turn, assigned participants to one of the estimated preference clusters that reflected their preferred product choice holistically. Moreover, possible demand effects are rather unlikely due to the 'none' option included, and only 40 percent of the offerings have led to choice. Experimental reliability is increased by design as each participant had to proceed with eight replications (i.e., choice sets). Regarding validity, we saw the presence of the conceptual understanding confirmed from our pre-test. Our discrete choice experiment with a full factorial design is more rigorous than streamlined variants with only a few decisions about many attributes. We have made the appropriate significance statements with caution due to the large sample size (Lin et al., 2013). Wherever possible, we pointed out the practical relevance and significance of the results bound to the respective group of conditions (Mohajeri et al., 2020).

\section{Future Research}

Further research avenues may follow this study. The preference formation for digital checking accounts may differ following situational norms in the digital realm, which is challenging to study. This development is accompanied by increasingly digitalized access paths to checking account providers. In the future, the primary bank relationship could be chosen via platform ecosystem providers, as the collaboration between Bigtech and major banks in the U.S. already demonstrates. Some customers (especially those prone to Fintech) may choose their checking account provider based on personalized recommendations in a digital product and service ecosystem they have already joined. Accordingly, it would make sense to examine the access paths to checking accounts and the relationship between checking accounts and additional banking services more in-depth in the future when customers are contracting with platform ecosystem providers. Mapping the customer journey and linking it to other banking or complementary ecosystem services could be indicated to gain further insights into Fintech customer choice. The frequency of digital interactions likely plays a role here, besides the innovative use cases that may lead to relationships with several checking accounts providers. For example, choice sets could be used to examine different usage scenarios for platform-based checking accounts in an experiment. This requires new experimental designs that integrate concrete usage patterns within the selection decisions. In this regard, scholars could also conduct revealed choice studies at digital platforms or comparisons portals. The uniqueness of the customer journey and new ways to access customers could be considered in future studies as situational factors, as we have not considered dynamic customer behavior in this study. Here, customers would have to evaluate concrete usage scenarios as influencing factors (instead of latent construct variables) to analyze how the customer segments can be mapped to complementary usage patterns. This could also be investigated ex-post, for example, with click-stream data from digital banking platforms in the future. However, platform-based offerings to investigate embedded finance customer journeys in a meaningful way are currently found primarily in Asia. Hence, this study would also need to be replicated with participants from other cultures. Analyzing established personality traits such as the "Big 5" would be another research opportunity (van Raaij, 2016). It would be exciting to see exactly which personality traits contribute to customers' resistance or openness to new types or forms of checking account providers. Finally, other industry sectors, such as insurance services, would provide a fruitful avenue to analyze the impact of digitalization on CDM. 


\section{Appendix 1}

Tables $6,7,8,9,10,11,12$ and 13

Table 6 Survey questionnaire (translated)

\begin{tabular}{lr}
\hline Construct & Source
\end{tabular}

Importance of trust

Gefen et al., 2003

With the chosen bank accounts, it was important to me

... that I feel that they are honest with their customers

... that I feel like they're taking care of the customers

... that they have high expertise

Calculative-based beliefs

Gefen et al., 2003

With the chosen bank accounts, it was important to me

... that they provide customers with expert advice

... that I feel that they are acting in the best interest of the customers

Structural assurances

Gefen et al., 2003

I would feel secure in doing business with banks

... because the general requirements of a banking license to be fulfilled by every provider protect my money

... because the security and bank guarantee of the providers strengthened my confidence

... because they will keep my personal information confidential

Market Mavenism

Feick \& Price, 1987

My friends seek my advice when they ask about bank accounts

People ask me for my opinion before they sign up for a new bank account

If someone asks me what the best bank accounts on the market are, I could tell them

Expressiveness

Nysveen et al., 2005

I often show my friends or family which digital banking products and services I use

I often talk with other people about banking products and services that I use

The banking products and services I use should leave an impression on other people

Situational normality

Gefen et al., 2003

With the chosen bank accounts, it was important to me

... that the products offered are most similar to the typical banking products currently available

... that the products offered are similar to those used by my friends or family

Perceived usefulness

Lu et al., 2005

With the chosen bank accounts, it was important to me

... that the services offered can be used productively

... that the services offered fulfill their tasks

... that the services offered are functional

Perceptual affinity

Bruyn \& Lilien, 2008

With the offerings I selected, it was important to me

... that I can identify with the offering personally

... that I like the offering personally

... that the offering meets my personal values

... that the services offered appeal to me emotionally

Loyalty

Methlie \& Nysveen, 1999

I have been a loyal customer at the same bank for years

Personal distress

Koller \& Lamm, 2014

I feel anxious and uncomfortable in decision-making situations

Sometimes I feel helpless when I am in the middle of a decision-making situation

Demographic

Please mark your gender

Which of the following age categories do you belong to?

What is your highest school or university degree? 
Table 7 Fornell-Larcker criterion

Table 8 HTMT

Table 9 Cross Loadings

\begin{tabular}{lllllllll}
\hline & ASS & CALC & EXP & MAV & PA & PD & PU & TRU \\
\hline ASS & 0.874 & & & & & & & \\
CALC & 0.509 & 0.897 & & & & & & \\
EXP & 0.116 & 0.048 & 0.859 & & & & & \\
MAV & 0.109 & 0.011 & 0.818 & 0.907 & & & & \\
PA & 0.453 & 0.519 & 0.202 & 0.155 & 0.795 & & & \\
PD & 0.016 & 0.058 & 0.049 & -0.041 & 0.137 & 0.908 & & \\
PU & 0.531 & 0.554 & 0.057 & 0.099 & 0.436 & -0.047 & 0.898 & \\
TRU & 0.565 & 0.85 & 0.089 & 0.049 & 0.539 & 0.059 & 0.574 & 0.859 \\
\hline
\end{tabular}

\begin{tabular}{lllllllll}
\hline & ASS & CALC & EXP & MAV & PA & PD & PU & TRU \\
\hline ASS & & & & & & & \\
CALC & 0.631 & & & & & & \\
EXP & 0.120 & 0.068 & & & & & \\
MAV & 0.131 & 0.087 & 0.925 & & & & \\
PA & 0.535 & 0.650 & 0.294 & 0.186 & & & \\
PD & 0.026 & 0.055 & 0.114 & 0.043 & 0.166 & & \\
PU & 0.615 & 0.676 & 0.097 & 0.120 & 0.490 & 0.075 & \\
TRU & 0.674 & 1.076 & 0.097 & 0.058 & 0.646 & 0.054 & 0.675 \\
\hline
\end{tabular}

\begin{tabular}{llllllllll}
\hline & ASS & CALC & EXP & MAV & NORM & PA & PD & PU & TRU \\
\hline EXP1 & 0.088 & 0.032 & 0.908 & 0.733 & 0.113 & 0.156 & 0.016 & 0.055 & 0.073 \\
EXP2 & 0.136 & 0.052 & 0.935 & 0.777 & 0.104 & 0.162 & 0.024 & 0.089 & 0.099 \\
EXP3 & 0.039 & 0.037 & 0.719 & 0.575 & 0.265 & 0.280 & 0.162 & -0.071 & 0.034 \\
MAV1 & 0.085 & 0.019 & 0.767 & 0.942 & 0.121 & 0.156 & -0.026 & 0.075 & 0.049 \\
MAV2 & 0.096 & 0.013 & 0.773 & 0.935 & 0.131 & 0.137 & -0.026 & 0.067 & 0.049 \\
MAV3 & 0.128 & -0.010 & 0.684 & 0.841 & 0.062 & 0.126 & -0.072 & 0.146 & 0.033 \\
PERC1 & 0.348 & 0.422 & 0.209 & 0.158 & 0.431 & 0.842 & 0.147 & 0.308 & 0.426 \\
PERC2 & 0.379 & 0.447 & 0.166 & 0.129 & 0.386 & 0.854 & 0.135 & 0.340 & 0.485 \\
PERC3 & 0.411 & 0.447 & 0.066 & 0.067 & 0.254 & 0.744 & 0.023 & 0.539 & 0.462 \\
PERC4 & 0.278 & 0.300 & 0.231 & 0.152 & 0.430 & 0.732 & 0.145 & 0.125 & 0.303 \\
PU1 & 0.461 & 0.484 & 0.082 & 0.102 & 0.145 & 0.416 & -0.051 & 0.886 & 0.501 \\
PU2 & 0.477 & 0.501 & 0.026 & 0.072 & 0.114 & 0.367 & -0.040 & 0.898 & 0.529 \\
PU3 & 0.491 & 0.507 & 0.047 & 0.092 & 0.162 & 0.393 & -0.036 & 0.911 & 0.516 \\
PD1 & 0.007 & 0.026 & 0.076 & -0.008 & 0.123 & 0.114 & 0.805 & -0.080 & 0.002 \\
PD2 & 0.016 & 0.058 & 0.048 & -0.042 & 0.133 & 0.136 & 1.000 & -0.046 & 0.060 \\
ASS1 & 0.859 & 0.394 & 0.107 & 0.106 & 0.249 & 0.337 & -0.005 & 0.461 & 0.440 \\
ASS2 & 0.894 & 0.459 & 0.123 & 0.128 & 0.285 & 0.424 & -0.001 & 0.455 & 0.516 \\
ASS3 & 0.869 & 0.477 & 0.074 & 0.055 & 0.239 & 0.418 & 0.044 & 0.476 & 0.519 \\
CALC1 & 0.399 & 0.889 & -0.003 & -0.053 & 0.348 & 0.457 & 0.061 & 0.436 & 0.736 \\
CALC2 & 0.511 & 0.904 & 0.086 & 0.068 & 0.300 & 0.473 & 0.043 & 0.553 & 0.788 \\
NORM1 & 0.310 & 0.372 & 0.072 & 0.061 & 0.940 & 0.402 & 0.082 & 0.216 & 0.361 \\
NORM2 & 0.148 & 0.194 & 0.248 & 0.192 & 0.725 & 0.402 & 0.187 & -0.027 & 0.179 \\
TRU1 & 0.504 & 0.744 & 0.077 & 0.035 & 0.266 & 0.477 & 0.050 & 0.524 & 0.866 \\
TRU2 & 0.499 & 0.769 & 0.057 & 0.020 & 0.321 & 0.489 & 0.075 & 0.486 & 0.888 \\
TRU3 & 0.452 & 0.674 & 0.098 & 0.076 & 0.307 & 0.420 & 0.022 & 0.469 & 0.821 \\
\hline & & & & &
\end{tabular}

ASS-Structural Assurances, CALC—Calculative-based beliefs, EXP-Expressiveness, MAV—Market Mavenism, PA-Perceptual Affinity,

PD—Personal Distress, PU—Perceived Usefulness, TRU—Importance of Trust. 
Table 10 Multigroup analysis of personal trust-related conditions

\begin{tabular}{|c|c|c|c|c|c|c|}
\hline \multirow[b]{3}{*}{ DV: Choice } & \multicolumn{6}{|c|}{ Personal trust-related conditions } \\
\hline & \multicolumn{2}{|l|}{ Importance of trust } & \multicolumn{2}{|c|}{ Calculative-based perceptions } & \multicolumn{2}{|c|}{ Structural assurances } \\
\hline & $\begin{array}{l}\text { Path-diff } \\
\text { (high trust - low trust) }\end{array}$ & $\begin{array}{l}\text { Path-diff } \\
\text { (very high trust - } \\
\text { very low trust) }\end{array}$ & $\begin{array}{l}\text { Path-diff } \\
\text { (high calc. - } \\
\text { low calc.) }\end{array}$ & $\begin{array}{l}\text { Path-diff } \\
\text { (very high calc. - } \\
\text { very low calc.) }\end{array}$ & $\begin{array}{l}\text { Path-diff } \\
\text { (high str. ass. - } \\
\text { low str. ass.) }\end{array}$ & $\begin{array}{l}\text { Path-diff } \\
\text { (very high str. ass. - } \\
\text { very low str. ass.) }\end{array}$ \\
\hline $\begin{array}{l}\text { Provider type } \\
\text { ("traditional bank") }\end{array}$ & 0.029 & 0.084 & $0.041 *$ & 0.061 & 0.029 & 0.080 \\
\hline $\begin{array}{l}\text { Scope of services ("both digital } \\
\text { and branch/store") }\end{array}$ & $-0.060 * * *$ & -0.006 & $-0.041^{*}$ & $-0.133^{* *}$ & -0.012 & $0.119 *$ \\
\hline $\begin{array}{l}\text { Customer service } \\
\text { experience ("high") }\end{array}$ & $-0.063 * * *$ & -0.075 & $-0.074 * * *$ & 0.017 & $-0.051 * *$ & 0.030 \\
\hline $\begin{array}{l}\text { Digital innovation } \\
\text { ("standard app") }\end{array}$ & 0.018 & -0.008 & 0.023 & -0.094 & 0.009 & -0.064 \\
\hline $\begin{array}{l}\text { Professional expertise } \\
\text { ("human customer advisor") }\end{array}$ & $-\mathbf{0 . 1 3 7} * * *$ & $-0.257 * * *$ & $-0.165 * * *$ & $-0.261 * * *$ & $-0.069 * * *$ & $-0.135 * *$ \\
\hline Group shares (respondents) & 119:926 & $25: 405$ & 152:954 & $18: 428$ & $238: 871$ & $24: 356$ \\
\hline
\end{tabular}

(Significance level: $* * * p<0.001, * * p<0.01, * p<0.05$ ).

Table 11 Multigroup analysis of social conditions

\begin{tabular}{|c|c|c|c|c|c|c|}
\hline \multirow[b]{3}{*}{ DV: Choice } & \multicolumn{6}{|c|}{ Social conditions } \\
\hline & \multicolumn{2}{|c|}{ Expressiveness } & \multicolumn{2}{|c|}{ Market mavenism } & \multicolumn{2}{|c|}{ Situational normality } \\
\hline & $\begin{array}{l}\text { Path-diff } \\
\text { (high expr. - } \\
\text { low expr.) }\end{array}$ & $\begin{array}{l}\text { Path-diff } \\
\text { (very high expr. - } \\
\text { very low expr.) }\end{array}$ & $\begin{array}{l}\text { Path-diff } \\
\text { (high mav. - } \\
\text { low mav.) }\end{array}$ & $\begin{array}{l}\text { Path-diff } \\
\text { (very high mav. - } \\
\text { very low mav.) }\end{array}$ & $\begin{array}{l}\text { Path-diff } \\
\text { (high sit norm. - } \\
\text { low sit norm.) }\end{array}$ & $\begin{array}{l}\text { Path-diff } \\
\text { (very high sit. norm. - } \\
\text { very low sit. norm.) }\end{array}$ \\
\hline $\begin{array}{l}\text { Provider type } \\
\text { traditional ("bank") }\end{array}$ & $0.063 * * *$ & $0.134 * * *$ & $0.055 * * *$ & $0.146 * * *$ & -0.027 & -0.052 \\
\hline $\begin{array}{l}\text { Scope of services ("both } \\
\text { digital and branch/store") }\end{array}$ & $0.119 * * *$ & $0.206 * * *$ & $0.120 * * *$ & $0.154 * * *$ & -0.022 & $-0.050^{* * * *}$ \\
\hline $\begin{array}{l}\text { Customer service } \\
\text { experience ("high") }\end{array}$ & $0.058 * * * *$ & $0.088^{*}$ & 0.011 & -0.022 & $0.095 * * *$ & $0.174 * * *$ \\
\hline $\begin{array}{l}\text { Digital innovation } \\
\text { ("standard app") }\end{array}$ & $0.045^{* *}$ & 0.054 & $0.042^{* *}$ & 0.042 & 0.007 & 0.001 \\
\hline $\begin{array}{l}\text { Professional expertise ("human } \\
\text { customer advisor") }\end{array}$ & $0.043 * *$ & 0.057 & $0.043 * *$ & $0.064^{*}$ & 0.011 & -0.025 \\
\hline Group shares (respondents) & 896:222 & 461:41 & 803:329 & $400: 64$ & 523:496 & 99:93 \\
\hline
\end{tabular}

(Significance level: $* * * p<0.001, * * p<0.01, * p<0.05)$.

Table 12 Multigroup analysis of attitudinal conditions

\begin{tabular}{|c|c|c|c|c|}
\hline \multirow[b]{3}{*}{ DV: Choice } & \multicolumn{4}{|l|}{ Attitudinal conditions } \\
\hline & \multicolumn{2}{|l|}{ Perceived usefulness } & \multicolumn{2}{|l|}{ Perceptual affinity } \\
\hline & $\begin{array}{l}\text { Path diff } \\
\text { (high pu. - low pu.) }\end{array}$ & $\begin{array}{l}\text { Path-diff } \\
\text { (very high pu. - } \\
\text { very low pu.) }\end{array}$ & $\begin{array}{l}\text { Path-diff } \\
\text { (high pa. - low pa.) }\end{array}$ & $\begin{array}{l}\text { Path-diff } \\
\text { (very high pa. - } \\
\text { very low pa.) }\end{array}$ \\
\hline $\begin{array}{l}\text { Provider type } \\
\text { ("traditional bank") }\end{array}$ & $0.079 * * *$ & 0.122 & 0.011 & 0.037 \\
\hline $\begin{array}{l}\text { Scope of services ("both } \\
\text { digital and branch/store") }\end{array}$ & -0.031 & 0.015 & -0.005 & -0.027 \\
\hline $\begin{array}{l}\text { Customer service } \\
\text { experience ("high") }\end{array}$ & $-0.172 * * *$ & -0.076 & $0.036 *$ & $0.106^{*}$ \\
\hline $\begin{array}{l}\text { Digital innovation } \\
\text { ("standard app") }\end{array}$ & -0.030 & -0.092 & $0.050 * * *$ & -0.002 \\
\hline $\begin{array}{l}\text { Professional expertise } \\
\text { ("human customer advisor") }\end{array}$ & $-\mathbf{0 . 1 1 0} * * *$ & -0.086 & -0.024 & $-0.115^{* *}$ \\
\hline Group shares (respondents) & 105:1059 & $10: 544$ & $339: 750$ & $40: 167$ \\
\hline
\end{tabular}

(Significance level: $* * * p<0.001, * * p<0.01, * p<0.05$ ). 


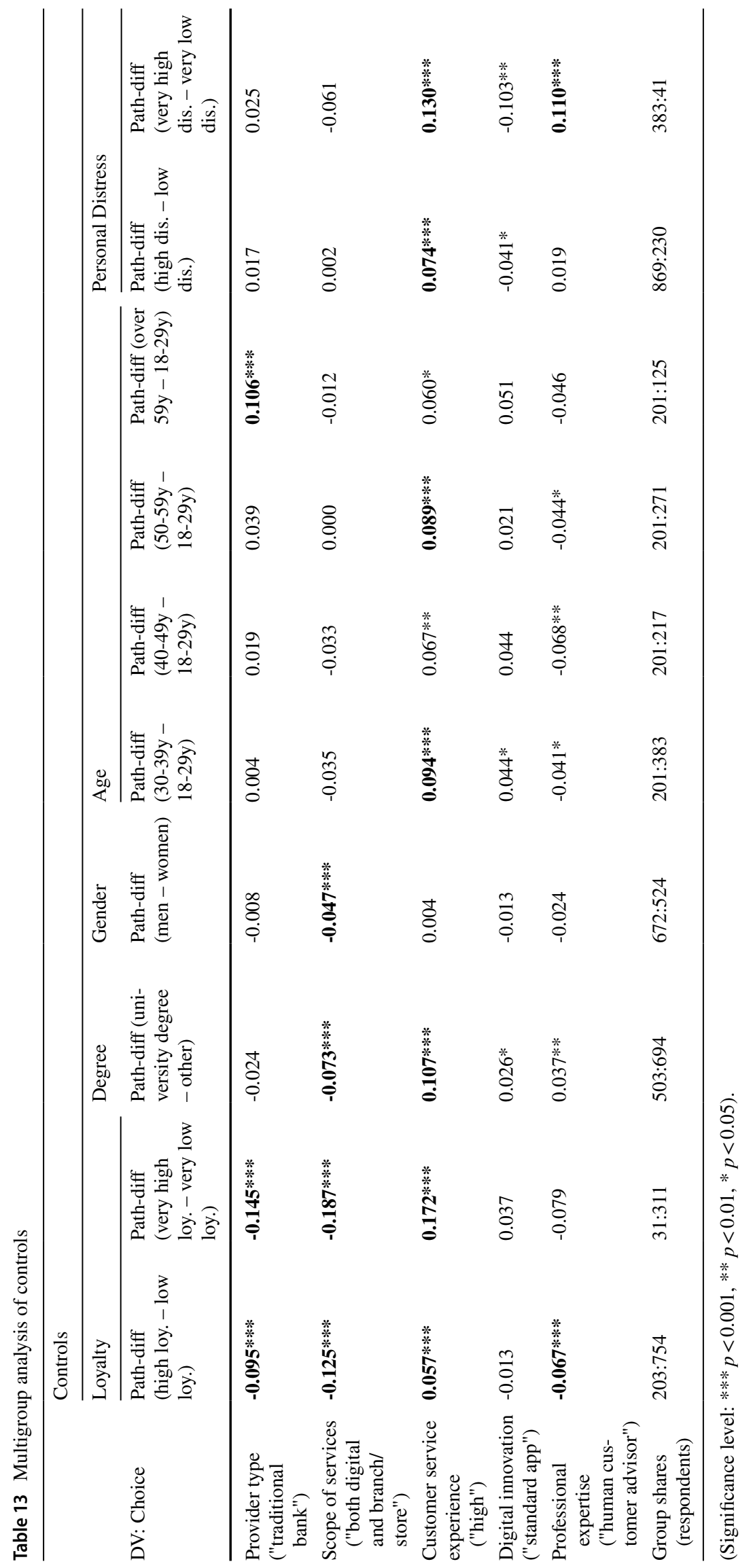


Funding Open Access funding enabled and organized by Projekt DEAL.

Open Access This article is licensed under a Creative Commons Attribution 4.0 International License, which permits use, sharing, adaptation, distribution and reproduction in any medium or format, as long as you give appropriate credit to the original author(s) and the source, provide a link to the Creative Commons licence, and indicate if changes were made. The images or other third party material in this article are included in the article's Creative Commons licence, unless indicated otherwise in a credit line to the material. If material is not included in the article's Creative Commons licence and your intended use is not permitted by statutory regulation or exceeds the permitted use, you will need to obtain permission directly from the copyright holder. To view a copy of this licence, visit http://creativecommons.org/licenses/by/4.0/.

\section{References}

Acar, O. A., \& Puntoni, S. (2016). Customer Empowerment in the Digital Age. Journal of Advertising Research, 56(1), 4-8. https:// doi.org/10.2501/JAR-2016-007

Accenture. (2020). Accenture Global Banking Consumer Study 2020: Making Digital More Human. Retrieved from https://www.accen ture.com/de-de/insights/banking/consumer-study-making-digit al-banking-more-human. Accessed December 10, 2021.

Almquist, E., Senior, J., \& Bloch, N. (2016). The 30 Elements of Consumer Value: A Hierarchy. Harvard Business Review(9). Retrieved from https://hbr.org/2016/09/the-elements-of-value. Accessed December 10, 2021

Alt, R., \& Puschmann, T. (2012). The rise of customer-oriented banking - electronic markets are paving the way for change in the financial industry. Electronic Markets, 22(4), 203-215. https:// doi.org/10.1007/s12525-012-0106-2

Alt, R., Ehmke, J. F., Haux, R., Henke, T., Mattfeld, D. C., Oberweis, A., \& Winter, A. (2019). Towards customer-induced service orchestration - requirements for the next step of customer orientation. Electronic Markets, 29(1), 79-91. https://doi.org/10. 1007/s12525-019-00340-3

Alt, R., \& Puschmann, T. (2014, May 12). Videoberatung löst Beratung ab. Frankfurter Allgemeine Zeitung.

Alt, R., \& Puschmann, T. (2016). Digitalisierung der Finanzindustrie: Grundlagen der Fintech-Evolution. Berlin, Heidelberg: Springer Gabler.

Andrews, R. L., \& Currim, I. S. (2003). Recovering and profiling the true segmentation structure in markets: An empirical investigation. International Journal of Research in Marketing, 20(2), 177-192. https://doi.org/10.1016/S0167-8116(03)00017-X

Ben-Akiva, M., Mcfadden, D., Train, K., Walker, J., Bhat, C., Bierlaire, M., \& Munizaga, M. A. (2002). Hybrid Choice Models: Progress and Challenges. Marketing Letters, 13(3), 163-175. https://doi.org/ 10.1023/A:1020254301302

Berger, S. C., \& Messerschmidt, C. M. (2009). Babbling before banking?: Online communities and pre-purchase information seeking. International Journal of Bank Marketing, 27(6), 446-466. https://doi.org/10.1108/02652320910988320

Berry, L. L., Seiders, K., \& Grewal, D. (2002). Understanding Service Convenience. Journal of Marketing, 66(3), 1-17. https://doi.org/ 10.1509/jmkg.66.3.1.18505

Blackwell, R. D., Miniard, P. W., \& Engel, J. F. (2002). Consumer behavior (9th ed.). South-Western Thomson Learning.
Bloch, P. H. (1995). Seeking the Ideal Form: Product Design and Consumer Response. Journal of Marketing, 59(3), 16. https://doi.org/ $10.2307 / 1252116$

Bodoff, D., \& Ho, S. Y. (2016). Partial Least Squares Structural Equation Modeling Approach for Analyzing a Model with a Binary Indicator as an Endogenous Variable. Communications of the Association for Information Systems, 38, 400-419. https://doi. org/10.17705/1CAIS.03823

Breinich-Schilly, A. (2020). Digitalisierung erschüttert Vertrauen in Banken nicht. Retrieved from https://www.springerprofessional. de/multikanal-banking/kundenservice/digitalisierung-erschuette rt-vertrauen-in-banken-nicht/17822798. Accessed December 10, 2021.

Brewster, S. (2016). Are you ready to trust your bank account to a team of chatbots? Retrieved from https://www.technologyreview. com/s/601418/do-your-banking-with-a-chatbot/. Accessed December 10, 2021.

Bud. (2020). Beyond Open Banking: 2020 and the road to Open Finance. Retrieved from https://www.thisisbud.com/ beyond-open-banking

Carbo-Valverde, S., Cuadros-Solas, P., \& Rodríguez-Fernández, F. (2020). A machine learning approach to the digitalization of bank customers: Evidence from random and causal forests. PLoS ONE, 15(10). https://doi.org/10.1371/journal.pone.02403 62

Charette, R. M. (2020). Inside the Hidden World of Legacy IT Systems. Retrieved from https://spectrum.ieee.org/computing/it/ inside-hidden-world-legacy-it-systems. Accessed December 10, 2021.

Chen, Y., Cheung, C. M., \& Tan, C. W. (2018). Omnichannel business research: Opportunities and challenges. Decision Support Systems, 109, 1-4. https://doi.org/10.1016/j.dss.2018.03.007

Collier, J. E., \& Kimes, S. E. (2013). Only If It Is Convenient: Understanding How Convenience Influences Self-Service Technology Evaluation. Journal of Service Research, 16(1), 39-51. https://doi.org/10.1177/1094670512458454

Dai, H., \& Salam, A. F. (2014). Does service convenience matter? An empirical assessment of service quality, service convenience and exchange relationship in electronic mediated environment. Electronic Markets, 24(4), 269-284. https://doi.org/10. 1007/s12525-014-0170-x

Davis, F. D. (1989). Perceived Usefulness, Perceived Ease of Use, and User Acceptance of Information Technology. MIS Quarterly, 13(3), 319. https://doi.org/10.2307/249008

de Bruyn, A., \& Lilien, G. L. (2008). A multi-stage model of wordof-mouth influence through viral marketing. International Journal of Research in Marketing, 25(3), 151-163. https:// doi.org/10.1016/j.ijresmar.2008.03.004

Dehnert, M. (2020). Sustaining the current or pursuing the new: Incumbent digital transformation strategies in the financial service industry. A configurational perspective on firm performance. Business Research, 13(3), 1071-1113. https://doi. org/10.1007/s40685-020-00136-8.

Dick, A. A. (2008). Demand estimation and consumer welfare in the banking industry. Journal of Banking \& Finance, 32(8), 1661-1676. https://doi.org/10.1016/j.jbankfin.2007.12.005

Ding, X. D., Huang, Y., \& Verma, R. (2011). Customer experience in online financial services: A study of behavioral intentions for techno-ready market segments. Journal of Service Management, 22(3), 344-366.

Dolnicar, S., \& Leisch, F. (2010). Evaluation of structure and reproducibility of cluster solutions using the bootstrap. Marketing Letters, 21(1), 83-101. https://doi.org/10.1007/ s11002-009-9083-4

Eickhoff, M., Muntermann, J., \& Weinrich, T. (2017). What do FinTechs actually do? A Taxonomy of FinTech Business Models. 
Proceedings of the International Conference on Information Systems.

Fang, S., Kwon, H. E., \& Park, Y. (2021). Impact of Digital-Only Bank Adoption on Consumer Consumption: Empirical Evidence. Proceedings of the International Conference on Information Systems.

Feick, L. F., \& Price, L. L. (1987). The Market Maven: A Diffuser of Marketplace Information. Journal of Marketing, 51(1), 83. https://doi.org/10.2307/1251146

Gefen, K., \& Straub. (2003). Trust and TAM in Online Shopping: An Integrated Model. MIS Quarterly, 27(1), 51. https://doi.org/10. 2307/30036519

Gefen D, Karahanna E, Straub D (2003) Trust and TAM in Online Shopping: An Integrated Model. MIS Quarterly. 27. 51-90. https://doi.org/10.2307/30036519

Gomber, P., Koch, J.-A., \& Siering, M. (2017). Digital Finance and FinTech: Current research and future research directions. Journal of Business Economics, 87(5), 537-580. https://doi.org/10.1007/ s11573-017-0852-X

Gomber, P., Kauffman, R. J., Parker, C., \& Weber, B. W. (2018). On the Fintech Revolution: Interpreting the Forces of Innovation, Disruption, and Transformation in Financial Services. Journal of Management Information Systems, 35(1), 220-265. https://doi. org/10.1080/07421222.2018.1440766

Groth, M., Wu, Y., Nguyen, H., \& Johnson, A. (2019). The Moment of Truth: A Review, Synthesis, and Research Agenda for the Customer Service Experience. Annual Review of Organizational Psychology and Organizational Behavior, 6(1), 89-113. https:// doi.org/10.1146/annurev-orgpsych-012218-015056

Grün, B., \& Leisch, F. (2008). FlexMix Version 2: Finite Mixtures with Concomitant Variables and Varying and Constant Parameters. Journal of Statistical Software, 28(4). https://doi.org/10.18637/ jss.v028.i04

Gupta, P., \& Tham, T. M. (2019). Fintech: The new DNA of financial services: De Gruyter. Retrieved from. https://doi.org/10.1515/ 9781547400904

Hair, J. F., Ringle, C. M., \& Sarstedt, M. (2011). PLS-SEM: Indeed a Silver Bullet. The Journal of Marketing Theory and Practice, 19(2), 139-152. https://doi.org/10.2753/MTP1069-6679190202

Hair, J. F., Hult, T. M., Ringle, C. M., \& Sarstedt, M. (2014). A primer on partial least squares structural equation modeling ( $P L S$ SEM). Sage Publ.

Hair, J. F., Sarstedt, M., Ringle, C. M., \& Gudergan, S. P. (2018). Advanced issues in partial least squares structural equation modeling. Sage.

Hair, J. F., Ringle, C. M., Gudergan, S. P., Fischer, A., Nitzl, C., \& Menictas, C. (2019). Partial least squares structural equation modeling-based discrete choice modeling: An illustration in modeling retailer choice. Business Research, 12(1), 115-142. https://doi.org/10.1007/s40685-018-0072-4

Helkkula, A., Kelleher, C., \& Pihlstrom, M. (2012). Characterizing Value as an Experience: Implications for Service Researchers and Managers. Journal of Service Research, 15(1), 59-75. https://doi.org/10.1177/1094670511426897

Henseler, J. (2012). PLS-MGA: A Non-Parametric Approach to Partial Least Squares-based Multi-Group Analysis. In W. A. Gaul, A. Geyer-Schulz, L. Schmidt-Thieme, \& J. Kunze (Eds.), Challenges at the Interface of Data Analysis, Computer Science, and Optimization (pp. 495-501). Berlin, Heidelberg: Springer. Retrieved from https://doi.org/10.1007/978-3-642-24466-7_50

Hoehle, H., Scornavacca, E., \& Huff, S. (2012). Three decades of research on consumer adoption and utilization of electronic banking channels: A literature analysis. Decision Support Systems, 54(1), 122-132. https://doi.org/10.1016/j.dss.2012.04.010
Homburg, C., Jozić, D., \& Kuehnl, C. (2017). Customer experience management: Toward implementing an evolving marketing concept. Journal of the Academy of Marketing Science, 45(3), 377-401. https://doi.org/10.1007/s11747-015-0460-7

Hurley, R., Gong, X., \& Waqar, A. (2014). Understanding the loss of trust in large banks. International Journal of Bank Marketing, 32(5), 348-366. https://doi.org/10.1108/IJBM-01-2014-0003

ING Group. (2019). ING International Survey - New Technologies 2019. Retrieved from https://think.ing.com/uploads/reports/ IIS_Mobile_Banking_-_New_Technologies_2019_FINAL.pdf. Accessed December 10, 2021.

Iqbal, Z., Verma, R., \& Baran, R. (2003). Understanding Consumer Choices and Preferences in Transaction-Based e-Services. Journal of Service Research, 6(1), 51-65. https://doi.org/10. $1177 / 1094670503254276$

Jünger, M., \& Mietzner, M. (2020). Banking goes digital: The adoption of FinTech services by German households. Finance Research Letters, 34, 101260. https://doi.org/10.1016/j.frl.2019.08.008

Kim, Y., \& Peterson, R. A. (2017). A Meta-analysis of Online Trust Relationships in E-commerce. Journal of Interactive Marketing, 38, 44-54. https://doi.org/10.1016/j.intmar.2017.01.001

King, B. (2019). Bank 40: Banking everywhere, never at a bank. Chichester: Wiley.

Kinting, M., \& Wißmann, S. (2016). Zukunftsfähiges Banking im perfekten Zusammenspiel zwischen Mensch und Technologie. In O. Everling \& R. Lempka (Eds.), Finanzdienstleister der nächsten Generation. Megatrend Digitalisierung: Strategien und Geschäftsmodelle (1st ed.). Frankfurt am Main: Frankfurt School Verlag. Retrieved from https://www.elaxy.de/files/pdf/DigitalerF inanzbetrieb.pdf. Accessed December 10, 2021.

Koller, I., \& Lamm, C. (2014). Item Response Model Investigation of the (German) Interpersonal Reactivity Index Empathy Questionnaire: Implications for Analyses of Group Differences. European Journal of Psychological Assessment, 31(3), 211-221. https:// doi.org/10.1027/1015-5759/a000227

Simon Kucher. (2019). Acquiring New Customers: Myths in Banking. Retrieved from https://www.simon-kucher.com/nl/blog/acqui ring-new-customers-myths-banking. Accessed December 10, 2021.

Kuhfeld, W. F., Tobias, R. D., \& Garratt, M. (1994). Efficient Experimental Design with Marketing Research Applications. Journal of Marketing Research, 31(4), 545. https://doi.org/10.2307/3151882

Laumann, J. (2013). Die Kunden-Berater-Passung als Quelle zukünftiger Erträge. Die Bank, 12, 80-83.

Lee, T. M. (2005). The impact of perceptions of interactivity on customer trust and transaction intentions in mobile commerce. Journal of Electronic Commerce Research, 6(3), 165.

Lee, M.-C. (2009). Factors influencing the adoption of internet banking: An integration of TAM and TPB with perceived risk and perceived benefit. Electronic Commerce Research and Applications, 8(3), 130-141. https://doi.org/10.1016/j.elerap.2008.11. 006

Leisch, F. (2004). FlexMix: A General Framework for Finite Mixture Models and Latent Class Regression in R. Journal of Statistical Software, 11(8). https://doi.org/10.18637/jss.v011.i08

Lewis, J. D., \& Weigert, A. (1985). Trust as a Social Reality. Oxford University Press, 63(4), 967-985.

Li, X., Hess, T. J., \& Valacich, J. S. (2008). Why do we trust new technology?: A study of initial trust formation with organizational information systems. The Journal of Strategic Information Systems, 17(1), 39-71. https://doi.org/10.1016/j.jsis.2008.01.001

Lin, M., Lucas, H. C., \& Shmueli, G. (2013). Research Commentary - Too Big to Fail: Large Samples and the p -Value Problem. Information Systems Research, 24(4), 906-917. https://doi.org/ 10.1287/isre.2013.0480 
Louviere, J. J., Street, D., Burgess, L., Wasi, N., Islam, T., \& Marley, A. A. (2008). Modeling the choices of individual decision-makers by combining efficient choice experiment designs with extra preference information. Journal of Choice Modelling, 1(1), 128-164. https://doi.org/10.1016/S1755-5345(13)70025-3

Louviere, J. J., Flynn, T. N., \& Carson, R. T. (2010). Discrete Choice Experiments Are Not Conjoint Analysis. Journal of Choice Modelling, 3(3), 57-72. https://doi.org/10.1016/S1755-5345(13) 70014-9

Lu, J., Yao, J. E., \& Yu, C.-S. (2005). Personal innovativeness, social influences and adoption of wireless Internet services via mobile technology. The Journal of Strategic Information Systems, 14(3), 245-268. https://doi.org/10.1016/j.jsis.2005.07.003

Maedche, A., Legner, C., Benlian, A., Berger, B., Gimpel, H., Hess, T., \& Söllner, M. (2019). AI-Based Digital Assistants. Business \& Information Systems Engineering, 61(4), 535-544. https://doi.org/ 10.1007/s12599-019-00600-8

Matsuo, M., Minami, C., \& Matsuyama, T. (2018). Social influence on innovation resistance in internet banking services. Journal of Retailing and Consumer Services, 45, 42-51. https://doi.org/10. 1016/j.jretconser.2018.08.005

Mbama, C. I., \& Ezepue, P. O. (2018). Digital banking, customer experience and bank financial performance: UK customers' perceptions. International Journal of Bank Marketing, 36(2), 230-255. https://doi.org/10.1108/IJBM-11-2016-0181

McFadden, D. L. (1984). Econometric analysis of qualitative response models. In Handbook of Econometrics (pp. 1395-1457). Amsterdam, New York: North-Holland.

McKinsey. (2019c). Thriving not just surviving in retail banking. Retrieved from https://www.mckinsey.com/industries/financialservices/our-insights/banking-matters/thriving-not-just-surviving

McKinsey. (2019a). Global Payments Report 2019. Retrieved from: https://www.mckinsey.com/ /media/mckinsey/industries/ financial $\% 20$ services/our $\% 20$ insights/tracking $\% 20$ the $\% 20$ sources $\% 20$ of $\% 20$ robust $\% 20$ payments $\% 20$ growth $\% 20$ mckinsey\%20global\%20payments\%20map/global-payments-report2019-amid-sustained-growth-vf.ashx

McKinsey. (2019b). The last pit stop? Time for bold late-cycle moves.: McKinsey Global Banking Annual Review 2019. Retrieved from https://www.mckinsey.com/industries/financial-services/ourinsights/global-banking-annual-review-2019-the-last-pit-stoptime-for-bold-late-cycle-moves. Accessed December 10, 2021.

McKnight, D. H., Cummings, L. L., \& Chervany, N. L. (1998). Initial Trust Formation in New Organizational Relationships. Academy of Management Review, 23(3), 473. https://doi.org/10.2307/ 259290

Methlie, L. B., \& Nysveen, H. (1999). Loyalty of on-line bank customers. Journal of Information Technology, 14(4), 375-386. https:// doi.org/10.1080/026839699344485

Milner, T., \& Rosenstreich, D. (2013). A review of consumer decisionmaking models and development of a new model for financial services. Journal of Financial Services Marketing, 18(2), 106-120. https://doi.org/10.1057/fsm.2013.7

Mistry, D. (2019). The Amazon-ification of banking. Retrieved from https://www.fintechfutures.com/2019/07/the-amazon-ificationof-banking/. Accessed December 10, 2021.

Mocker, M., \& Ross, J. W. (2013). Architecting customer experience at USAA. Proceedings of the International Conference on Information Systems.

Mohajeri, K., Mesgari, M., \& Lee, A. S. (2020). When Statistical Significance Is Not Enough: Investigating Relevance, Practical Significance, and Statistical Significance. MIS Quarterly, 44(2), 525-559. https://doi.org/10.25300/MISQ/2020/13932

Naous, D., \& Legner, C. (2020). Leveraging Market Research Techniques in IS - A Review and Framework of Conjoint Analysis Studies in the IS
Discipline. Communications of the Association for Information Systems, 49(1), 126-155. https://doi.org/10.17705/1CAIS.04906

Nüesch, R., Alt, R., \& Puschmann, T. (2015). Hybrid Customer Interaction. Business \& Information Systems Engineering, 57(1), 73-78. https://doi.org/10.1007/s12599-014-0366-9

Nysveen, H., Pedersen, P. E., \& Thorbjørnsen, H. (2005). Intentions to use mobile services: Antecedents and cross-service comparisons. Journal of the Academy of Marketing Science, 33(3), 330. https:// doi.org/10.1177/0092070305276149

Ohlwein, M. (1999). Märkte für gebrauchte Güter. Deutscher Universitätsverlag.

Okazaki, S., \& Mendez, F. (2013). Perceived Ubiquity in Mobile Services. Journal of Interactive Marketing, 27(2), 98-111. https:// doi.org/10.1016/j.intmar.2012.10.001

Ologeanu-Taddei, R., \& Vitari, C. (2020). Filling gaps and re-conceptualizing trust in Information Technology. Proceedings of the European Conference on Information Systems.

Pedersen, L. B., Kjær, T., Kragstrup, J., \& Gyrd-Hansen, D. (2011). Does the Inclusion of a Cost Attribute in Forced and Unforced Choices Matter? Journal of Choice Modelling, 4(3), 88-109. https://doi.org/10.1016/S1755-5345(13)70044-7

Pickford, J. (2019). Mobile banking and contactless cards continue to surge in popularity. Retrieved from https://www.ft.com/content/ 7106e354-8846-11e9-a028-86cea8523dc2. Accessed December $10,2021$.

Podsakoff, P. M., MacKenzie, S. B., Lee, J.-Y., \& Podsakoff, N. P. (2003). Common method biases in behavioral research: A critical review of the literature and recommended remedies. The Journal of Applied Psychology, 88(5), 879-903. 903. https:// doi.org/10.1037/0021-9010.88.5.879

Pousttchi, K., \& Dehnert, M. (2018). Exploring the digitalization impact on consumer decision-making in retail banking. Electronic Markets, 28(3), 265-286. https://doi.org/10.1007/ s12525-017-0283-0.

Punj, G. N., \& Stewart, D. W. (1983). An Interaction Framework of Consumer Decision Making. Journal of Consumer Research, 10(2), 181. https://doi.org/10.1086/208958

PwC. (2018). Der Einfluss von Customer Experience im Bereich Banken und Versicherer. Retrieved from https://www.pwc.de/ de/finanzdienstleistungen/der-einfluss-von-customer-exper ience-im-bereich-banken-und-versicherer.html. Accessed December 10, 2021.

PwC. (2020a). Financial Service Technology 2020 and Beyond. Retrieved from https://www.pwc.com/gx/en/financial-servi ces/assets/pdf/technology2020-and-beyond.pdf. Accessed December 10, 2021.

PwC. (2020b). Individueller Service per Chatbot: Mobile Filialbank - Banking nah am Kunden. Retrieved from https://www.pwc. de/de/finanzdienstleistungen/banken/individueller-serviceper-chatbot-mobile-filialbank-banking-nah-am-kunden.html. Accessed December 10, 2021.

PwC. (2021). Beziehungsmanagement bei Banken Privatkund:innen. Retrieved from https://www.pwc.de/de/ finanzdienstleistungen/banken/wie-banken-das-beziehungs management-mit-ihren-kunden-gestalten-2021.pdf. Accessed December 10, 2021.

PYMNTS. (2019). Where Will We Bank Next? Retrieved from https:// www.pymnts.com/study/where-will-we-bank-next-april-2019/. Accessed December 10, 2021.

Roland Berger. (2015). Digitale Revolution im Retail-Banking: Chancen in der neuen Multikanal-Welt aus Kundensicht. Retrieved from https://www.visa.de/uber-visa/presse-undnews/studiendownload-digitale-revolution-im-retail-banking107470? returnUrl=/uber-visa/presse-und-news/listing?type= news. Accessed December 10, 2021. 
Roland Berger. (2021). Has the bank branch had its day?: The future of retail bank networks - A global perspective with a focus on Southeast Asia. Retrieved from https://www.rolandberger. com/en/Insights/Publications/Has-the-bank-branch-had-itsday.html. Accessed December 10, 2021.

Rousseau, D. M., Sitkin, S. B., Burt, R. S., \& Camerer, C. (1998). Introduction to Special Topic Forum: Not so Different after All: A Cross-Discipline View of Trust. The Academy of Management Review, 23(3), 393-404.

Scherer, A., Wünderlich, N. V., \& Wangenheim, F. V. (2015). The Value of Self-service: Long-term Effects of Technology-based Self-service Usage on Customer Retention. MIS Quarterly, 39(1), 177-200. Retrieved from http://dl.acm.org/citation.cfm? id=2871299.2871309. Accessed December 10, 2021.

Schiffman, L. G., \& Kanuk, L. L. (1997). Consumer behavior (6th ed.). Prentice Hall.

Shevlin, R. (2021). The 12 Most Important Mobile Banking Features (And Why No Bank Can Have Them All). Retrieved from https://www.forbes.com/sites/ronshevlin/2021/03/29/new-resea rch-identifies-the-most-critical-mobile-banking-features/?sh= 48b8ac371851. Accessed December 10, 2021.

Skinner, C. (2014). Digital Bank: Strategies to launch or become a digital bank. Singapore: Marshall Cavendish.

Skinner, C. (2020). Doing digital: Lessons from leaders (1st ed.). Marshall Cavendish Business.

Skinner, C. (2021). People need people, not just apps. Retrieved from https://thefinanser.com/2021/10/people-need-people-notjust-apps.html/. Accessed December 10, 2021.

Solomon, M. R., Bamossy, G. J., Askegaard, S. T., \& Hogg, M. K. (2013). Consumer behaviour: A European perspective (5th ed.). Pearson.

Street, D. J., \& Burgess, L. (2007). The construction of optimal stated choice experiments: Theory and methods. Wiley series in probability and statistics. Wiley.
Tam, C., \& Oliveira, T. (2019). Does culture influence m-banking use and individual performance? Information \& Management, 56(3), 356-363. https://doi.org/10.1016/j.im.2018.07.009

The Financial Brand. (2017). Customer Segmentation Models In Banking Are Broken. Retrieved from https://thefinancialbrand.com/ 67137/customer-segmentation-demographic-models/?JMTW. Accessed December 10, 2021.

Train, K. (2009). Discrete choice methods with simulation (2nd ed.). Cambridge University Press.

van Raaij, W. F. (2016). Understanding consumer financial behavior: Money management in an age of financial illiteracy. Palgrave Macmillan.

Verma, R., Iqbal, Z., \& Plaschka, G. (2004). Understanding Customer Choices in E-Financial Services. California Management Review, 46(4), 43-67. https://doi.org/10.2307/41166274

Xin Ding, D., Hu, P.J.-H., Verma, R., \& Wardell, D. G. (2010). The Impact of Service System Design and Flow Experience on Customer Satisfaction in Online Financial Services. Journal of Service Research, 13(1), 96-110. https://doi.org/10.1177/10946 70509350674

Xu, J., Benbasat, I., \& Cenfetelli, R. (2011). The Effects of Service and Consumer Product Knowledge on Online Customer Loyalty. Journal of the Association for Information Systems, 12(11), 741-766. https://doi.org/10.17705/1jais.00279

Zavolokina, L., Dolata, M., \& Schwabe, G. (2016). FinTech - What's in a Name? Proceedings of the International Conference on Information Systems.

Zhou, M., Geng, D., Abhishek, V., \& Li, B. (2020). When the Bank Comes to You: Branch Network and Customer Omnichannel Banking Behavior. Information Systems Research, 31(1), 176197. https://doi.org/10.1287/isre.2019.0880

Publisher's Note Springer Nature remains neutral with regard to jurisdictional claims in published maps and institutional affiliations. 